NASA TECHNICAL NOTE

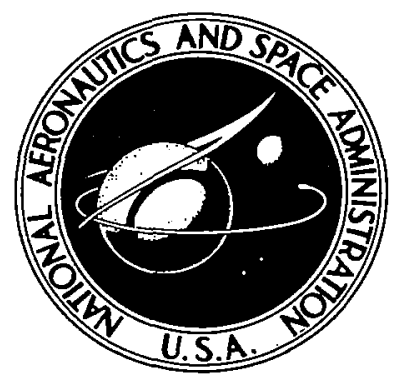

NASA TN D-7014 C.i

LOAN COPY: RETUR! AFWL (DOGL) KIRTLAND AFB, N.

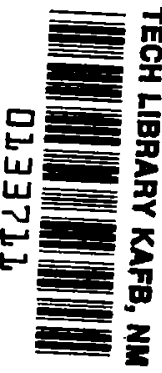

\title{
REINGESTION CHARACTERISTICS \\ AND INLET FLOW DISTORTION \\ OF V/STOL LIFT-ENGINE \\ FIGHTER CONFIGURATIONS
}

by Jerry $V$. Kirk and Jerry P. Barrack

Ames Research Center

Moffett Field, Calif. 94035

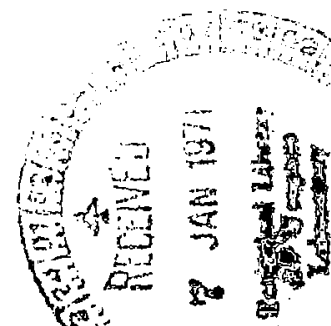

national aeronautics and SPACE adMinistration - Washington, D. C. - DeCEMBber 1970 
1. Report No. NASA TN D-7014

4. Titie and Subtitle

REINGESTION CHARACTFRISTICS AND INLET FLOW DISTORTION OF V/STOL LIFT-ENGINE FIGHTER CONFIGURATIONS

\section{Author(s)}

Jerry V. Kirk and Jerry P. Barrack

9. Performing Organization Name and Address

NASA Ames Research Center

Moffett Field, Calif., 94035

National Aeronautics and Space Administration

Washington, D. C., 20546

15. Supplementary Notes
3. Recipient's Catalog No.

5. Report Date

December 1970

6. Performing Organization Code

8. Performing Organization Report No. A-2996

10. Work Unit No.

721-01-00-15-00-21

11. Contract or Grant No.

13. Type of Report and Period Covered Technical Note

14. Sponsoring Agency Code

16. Abstract

Reingestion of exhaust gas into engine inlets during hover, and inlet flow distortion with the associated loss in total-pressure recovery during transition were studied using a largescale generalized lift-engine fighter model powered by $\mathrm{J}-85$ engines. Exhaust gas reingestion during hover was studied on a static test facility, and inlet flow distortion and total-pressure recovery loss were studied in the 40 - by 80 -foot wind tunnel. Two lift-engine arrangements were studied, the swiveling, retractable and the internally fixed.

Both arrangements were subject to excessive thrust loss and compressor stalls due to reingestion when the engine exhaust was vectored nearly vertical. Vectoring the exhaust approximately $20^{\circ}$ from vertical essentially eliminated reingestion problems. Vectoring the lift-engine exhaust forward and the lift-cruise engine exhaust aft to balance the aircraft and minimize reingestion appears to be a feasible means of allowing VTOL operation. Inlet flow distortion and total-pressure recovery were within acceptable limits for the swiveling, retractable lift-engine configuration. With the inlet guide vane installed to help turn the flow into the engine, the vertically mounted lift engines of the internally fixed configuration with an inlet radius to diameter ratio of 0.19 produced acceptable inlet flow distortion and totalpressure recovery results. Without the guide vane the nominal acceptable distortion level of 10 percent was exceeded at the higher velocity ratios.

17. Key Words (Suggested by Author(s))

Exhaust gas reingestion

Inlet flow distortion

Pressure recovery loss
18. Distribution Statement

Unclassified-Unlimited
19. Security Classif. (of this report Unclassified
20. Security Classif. (of this page) Unclassified
21. No. of Pages

41
22. Price*

$\$ 3.00$

\footnotetext{
For sale by the National Technical Information Service, Springfield, Virginia 22151
} 


\section{NOTATION}

D

E.G.P.

$F_{g}$

H

N

$\mathrm{p}$

$\frac{p_{t_{a v}}}{p_{t_{0}}}$

q

Q

$r$

$T$

$\triangle \mathrm{T}$

V

W

$\alpha$

$\beta$

$\eta$

م

$\sigma$ inlet or exit diameter, in.

average exhaust gas pressure, psig

engine gross thrust, Ib

height of model above ground, in.

inlet pressure distortion, $\frac{p_{t_{\max }}-p_{t_{\text {min }}}}{p_{t_{a v}}}$

pressure, psi

engine inlet total-pressure recovery

dynamic pressure, $(1 / 2)_{\circ} V^{2}$, psf

temperature distortion, $\frac{T_{\max }-T_{\min }}{T_{a v}},{ }_{R}$

radius, in.

temperature, ${ }^{\circ} \mathrm{F}$ or ${ }^{{ }^{\circ}} \mathrm{R}$

temperature rise above ambient, ${ }^{\circ} \mathrm{F}$

velocity, fps

fuselage width, in.

angle of attack, deg

angle of sideslip, deg

angle between the engine axis and a vertical plane normal to the swivel axis, deg

density, $1 \mathrm{~b} / \mathrm{ft}^{3}$

angle between engine exhaust axis and the horizontal measured in a plane perpendicular to the swivel axis, deg 


\section{Subscripts}

av

C

e

i

L

$\circ$ average

lift-cruise engine

exit

inlet

lift engine

free stream 
REINGESTION CHARACTERISTICS AND INLET FLOW DISTORTION OF

$\mathrm{V} /$ STOL LIFT-ENGINE FIGHPER CONFIGURATIONS*

Jerry V. Kirk and Jerry P. Barrack

Ames Research Center

SUMMARY

Reingestion of exhaust gas into engine inlets during hover, and inlet flow distortion with the associated loss in total-pressure recovery during transition were studied using a large-scale generalized lift-engine fighter model powered by J-85 engines. Exhaust gas reingestion during hover was studied on a static test facility, and inlet flow distortion and total-pressure recovery loss were studied in the 40-by 80-foot wind tunnel. Two lift-engine arrangements were studied, the swiveling, retractable and the internally fixed.

Both arrangements were subject to excessive thrust loss and compressor stalls due to reingestion when the engine exhaust was vectored nearly vertical. Vectoring the exhaust approximately $20^{\circ}$ from vertical essentially eliminated reingestion problems. Vectoring the lift-engine exhaust forwara and the liftcruise engine exhaust aft to balance the aircraft and minimize reingestion appears to be a feasible means of allowing VTOL operation. Inlet flow distortion and total-pressure recovery were within acceptable limits for the swiveling, retractable lift-engine configuration. With the inlet guide vane installed to help turn the flow into the engine, the vertically mounted lift engines of the internally fixed configuration with an inlet radius to diameter ratio of 0.19 produced acceptable inlet flow distortion and total-pressure recovery results. Without the guide vane the nominal acceptable distortion level of 10 percent was exceeded at the higher velocity ratios.

\section{INTRODUCTION}

Past research (refs. 1 - 4) has shown that reingestion of exhaust gas and flow distortion in the lift-engine inlet are major problems for V/STOL aircraft during hover and transition. At best, reingestion reduces takeoff performance and may cause compressor surge. The effect of aircraft configuration on this problem was reported in references 1 and 4. This paper will discuss efforts to reduce ingestion on an aircraft configuration optimized for cruise without regard to ingestion. Airflow distortion at the lift-engine compressor face was shown in reference $I$ to be reduced to acceptable values by an inlet with a ratio of lip radius to inlet diameter of 0.56 when the engine was tilted so that the inlet was $10^{\circ}$ forward of vertical. Since these dimensions result in a rather bulky installation, recent research at Ames has been directed toward achieving an acceptable flow with vertically mounted lift engines and a smaller inlet radius.

*The results of this study were summarized at the AIAA 6th Aerospace Sciences Meeting, New York City, January 22-24, 1968. 
The studies were made on a large-scale model of a lift-engine-powered aircraft representative of a variable-sweep fighter. Results from the Ames hover test facility will be presented showing inlet temperature rise and temperature gradients for different exhaust angles and ground heights for two lift-engine configurations, one with swiveling, retractable engines and one with internally fixed engines. Minor modifications to the model to alleviate the reingestion problem will be discussed.

Results from investigations in the 40- by 80-foot wind tunnel to determine inlet flow distortion and inlet total-pressure recovery are presented for both configurations. The effects of an inlet guide vane on the internally fixed configuration are shown for a range of flight speeds, power settings, and airplane angles of attack and sideslip.

\section{MODET AND INSTRUMENTATION}

The model (fig. I) had a high wing and was representative of a variablesweep fighter aircraft. The wings were in the forward or unswept position for the entire investigation. Forty-percent chord single-slotted flaps extended from the wing fuselage juncture to the 75-percent semispan wing station and were deflected $40^{\circ}$ throughout the study. Twenty-percent chord leading-edge slats spanned the wing from the junction of the fixed and movable section of the wing to the wing tip and were deflected $25^{\circ}$.

The lift engines were YJ85-5 turbojets without afterburners. For the swiveling, retractable configuration, two lift engines were mounted on each side of the fuselage. The swiveling feature made it possible to direct the exhaust at angles $(\sigma)$ from $30^{\circ}$ to $110^{\circ}$. Tests were conducted with the engines in $a 5^{\circ}$ and a $20^{\circ}$ swivel plane (fig. 1); in both planes, the engines could be canted $15^{\circ}$. When the swivel plane was changed from $5^{\circ}$ to $20^{\circ}$, the wing leading-edge strake was extended farther forward on the fuselage, thus changing the leading-edge sweep angle from $60^{\circ}$ to $70^{\circ}$.

The internally fixed configuration had three in-line lift engines installed vertically in the forward fuselage (fig. 2). Three different liftengine exit nozzles (shown in fig. 3) were used during the ingestion studies with this configuration. The conical nozzle was similar to the conventional nozzle used with the swiveling, retractable configuration; the bifurcated nozzle was used to simulate side-by-side mounted lift engines by splitting the exhaust from each of the three lift engines; the slotted nozzle was used to promote exhaust gas pressure decay and thereby reduce the effects of ground erosion and inlet ingestion. Louvers beneath the conical and slotted nozzles directed the exhaust flow from $30^{\circ}$ to $90^{\circ}$, while flange joints permitted the bifurcated nozzles to be swiveled from $30^{\circ}$ to $90^{\circ}$.

Both configurations had two lift-cruise engines (YJ85-5 turbojets) installed in the aft fuselage with the inlets above the wing. For the swiveling, retractable configuration, the lift-cruise engine exhaust nozzles were pivoted to correspond with the lift-engine angles to provide approximate 
thrust vectors to balance the model in a level attitude. These nozzles could also be pivoted to locate the thrust axis for cruise flight.

An inlet duct extension was placed forward of the lift-cruise engines when the lift engines were in the $5^{\circ}$ swivel plane (fig. 1). The purpose was to evaluate the effect of a lengthened duct as a mixing chamber for the air entering the lift-cruise engines.

The lift-cruise engine exhaust in the internally fixed configuration was controlled for either lift or cruise by a diverter valve. For lift, louvers beneath the exhaust, as with the lift engines, vectored the flow from $30^{\circ}$ to $82^{\circ}$.

Figure 4 shows the model mounted on the static test stand and in the Ames 40 - by 80 -Foot Wind Tunnel. For the exhaust gas reingestion studies simulated doors were mounted between the lift engines and the fuselage on the swiveling, retractable configuration (fig. 4(a)). Limited tests were made with the doors extending outward from the bottom of the fuselage on the internally fixed configuration (fig. 4(b)). The purpose of these doors was to deflect the rapidly rising exhaust gases away from the lift-engine inlet area. However, similar doors could be used to cover the swiveling, retractable lift engines in the stowed position or to seal the bottom of the fuselage on the internally fixed configuration when the lift engines were not in use.

Figure 5 shows the geometry of the lift-engine inlets for the two configurations. A semicircular inlet vane around the forward half of the internally fixed lift-engine inlets (fig. 5(b)) helped turn the flow into the vertically mounted engines during transition.

\section{Reingestion Instrumentation}

Engine inlet air temperature histories are of a highly transient character for many of the configurations tested. Thermocouples of small enough thermal mass to follow the actual temperature transients will not withstand the vibration and acoustic environment within an engine inlet. However, since instantaneous temperature is highly important, it is possible, with a mechanically suitable thermocouple, to reconstruct the actual input temperature history from the output temperature history and the thermocouple response characteristics. For example, reference 4 shows the development of the temperature calculation and the correlation between experiment and theory for a full-scale configuration with thermocouples similar to those used in this investigation (i.e., iron constantan wire 0.005 and 0.010 in. in diameter having time constants of 30 to $100 \mathrm{~ms}$ ).

Each of the 4 lift-engine inlets of the swiveling, retractable configuration had 12 thermocouples whereas the 3 inlets of the internally fixed lift engines had 16. The left-hand lift-cruise engine on both configurations was instrumented at the compressor face with 16 thermocouples. When the duct extension was installed (swiveling, retractable configuration only), 9 thermocouples were installed at the inlet plane. 
Fxhaust gas total pressure was measured on all engines of both configurations to monitor engine performance as reingestion occurred. Each tailpipe was fitted with four total pressure probes ganged together to provide the required measurement of exhaust gas pressure.

\section{Pressure Distortion Instrumentation}

Sixteen area-weighted total-pressure tubes were placed in each liftengine inlet and the left-hand lift-cruise engine inlet for measuring steadystate inlet distortion and total-pressure recovery during transition for both configurations.

TESTING AND PROCEDURE

\section{Reingestion Studies}

Test variables- Exhaust gas reingestion studies were conducted on an outdoor static test facility at varying ground heights. The swiveling, retractable lift engines were rotated from $20^{\circ}$ forward to $20^{\circ}$ aft $\left(\sigma=110^{\circ}\right.$ to $70^{\circ}$ ) of vertical at each ground height. In addition to vectoring, other methods used to minimize ingestion for this configuration were:

protection.

1. Extending the wing strake toward the lift-engine inlets for

2. Fxtending the lift-cruise engine-inlet duct to act as a mixing chamber for air entering the inlet.

3. Mounting simulated doors between the fuselage and engines to interrupt the flow path between the engines and the fuselage.

4. Canting the engines up to $15^{\circ}$ outboard perpendicular to the swivel plane (toe out).

The lift-engine exhaust of the internally fixed configuration, was vectored from vertical to $20^{\circ}$ aft $\left(\sigma=90^{\circ}\right.$ to $\left.70^{\circ}\right)$ with the three separate exhaust nozzles (conical, bifurcated, and slotted) at each ground height. As with the swiveling, retractable configuration, some studies were made with doors along the bottom of the fuselage to prevent recirculation of the hot exhaust gases.

Operating procedures-At each ground height and exhaust vector angle, the engines were started individually and accelerated to 70 percent RPM. Recording equipment was then started and the engines were simultaneously accelerated to 100 percent RPM, a process that took approximately 3 seconds. A continous record of inlet temperature and engine exhaust gas pressure was maintained for 5 to 20 seconds depending on ground proximity and severity of reingestion. The engines were then decelerated and shut down. 


\section{Inlet Pressure Distortion in Transition}

Inlet distortion and total-pressure recovery were studied in the $40-$ by 80-foot wind tunnel. Engire thrust levels, vector angles $(\sigma)$, and wind-tunnel forward speeds were varied with the model at a constant angle of attack $\left(0^{\circ}\right)$ to give a range of inlet velocity ratios representative of the transition from hover to wing-supported flight. Thrust level, vector angle, and wind-tunnel forward speed were held essentially constant when angle of attack or angle of sideslip was varied.

\section{RESULTS AND DISCUSSION}

\section{Exhaust Gas Reingestion}

Two distinct types of exhaust gas reingestion occur in lift-engine powered V/STOL configurations. One type is characterized by exhaust spreading along the ground some distance from the aircraft. After greatly decreasing in velocity, this gas, because of its bouyancy, eventually recirculates to the engine inlets. The mixing of exhaust gas with ambient air, raises the temperature at the inlet a few degrees higher than the ambient air temperature. This type of ingestion will cause performance loss but is rarely catastrophic.

The other type of exhaust gas reingestion is usually caused by the meeting of adjacent high velocity jets. Their interaction results in an upward flow of high-temperature gases. If the upward flow is near an inlet, there is little oppoxtunity for the gas to cool by mixing with ambient air. This hot gas usually enters the engine inlet in a localized region and can cause the engine to stall. Ingestion of this type is more serious and is the subject of the following discussion.

Flow patterns- Tuft studies showed that the hot exhaust from the swiveling, retractable lift-engine configuration followed two distinct upward patterns. One formed under the fuselage between the lift engines (fig. 6(a)) while the other formed where the exhaust gases from the lift-engines flowing aft met the forward-flowing exhaust from the lift-cruise engines. The first flow arose on either side of the fuselage between the fuselage and lift engines to the vicinity of the engine inlets while the second was channeled by the wing into the vicinity of the lift-engine inlets. Parallel swiveling of the lift engines and lift-cruise engine nozzles changed the location of the fountains of hot exhaust gas. Regardless of the engine swivel angle, the lift-cruise engine inlets were relatively free of exhaust-gas reingestion. The wing appeared to offer sufficient protection to the lift-cruise engine inlets with and without the inlet duct extension.

Placing doors between the fuselage and the lift engines reduced the upward flow of exhaust gases from the forward fountain (as indicated by tufts); however, exhaust that flowed around the doors (all results shown are with these doors) and met the high temperature turbulent flow from the rear fountain was still channeled by the wing into the vicinity of the lift-engine inlets. 
The three lift engines in the internally fixed configuration were spaced close together so that the exhaust coalesced to form a single sheet of hot exhaust. Flowing aft this exhaust joined the forward flowing exhaust from the lift-cruise engines. The rising turbulent flow was channeled by the undersurface of the wing and wing leading-edge strake into the vicinity of the lift-engine inlets (fig. 6(b)). Again, the lift-cruise engine inlets experienced very light reingestion in most instances.

Test results- The reingestion characteristics obtained for both configurations are summarized in table 1 . The table shows the various ground heights (ground height to engine exit diameter ratio) and engine vector angles tested with remarks about the reingestion characteristics. The results in table 1 are for wind conditions of less than 3-5 knots; the majority are for no wind. Wind conditions could significantly alter the reingestion characteristics. Height to diameter ratios between 5.0 and 7.5 seemed to be critical. For this reason, the results shown in figures 7 through 15 are for an $H / D=5.0$. Figures 7 through 9 show results for the four lift engines of the swiveling, retractable configuration with the lift engines in the $20^{\circ}$ swivel plane, canted $15^{\circ}$, and no extension on the lift-cruise engine duct. Simulated doors (see fig. 4(a)) were mounted between the lift engines and the fuselage to reduce upward flow from the forward fountain. The results in figure 7 are for the lift engines swiveled to $90^{\circ}$ and the lift-cruise exit nozzles pivoted to $70^{\circ}$. This arrangement essentially balanced the thrust vectors to simulate a vertical takeoff. Thermocouple traces are shown for all rakes of each of the four lift engines. Engines I through 3 incurred varying amounts of exhaust gas ingestion throughout the run. The number 4 engine ( $f i g .7(d)$ ) stalled at just over 4 seconds on the time scale. Measured average inlet temperature rise across the inlet during stall and backfire was $145^{\circ}$ with maximum temperature gradients on the order of $1000^{\circ} /$ second. When corrected for thermocouple response, by the method of reference 4 , these values are $157^{\circ}$ and $1700^{\circ} /$ second. This engine ingested hot gas throughout the acceleration cycle as evidenced by the thermocouple traces and the fluctuating exhaust gas pressure trace to the point of stal1. The highest temperature rise was measured on the rakes at the 3 and $60^{\prime}$ clock positions on the engine. Similar results are shown in figure 8 for the lift engines swiveled to $80^{\circ}$ and the lift-cruise exit nozzles pivoted to $70^{\circ}$. The results are for the engines operating at 100 percent RPM at zero time. Engine number 4, in this example, ran for a time at maximum RPM before stalling; however, engine thrust degradation throughout the run is apparent from fluctuations of the exhaust gas pressure trace. At the point of engine stall, the measured average inlet temperature rise was $90^{\circ}$ while the maximum temperature gradient was $1200^{\circ}$ /second. Corresponding calculated values were $132^{\circ}$ average inlet temperature rise with maximum temperature gradients of $2100^{\circ} /$ second. Figure 9 gives an example of low ingestion with the lift engines swiveled to $70^{\circ}$ and the lift-cruise exhaust nozzles at $65^{\circ}$. Little or no ingestion was measured throughout the run, as indicated by the average $\Delta T$ and exhaust gas pressure traces for the four lift engines.

The average inlet temperature and distortion index (corrected for thermocouple response) are shown in figure 10 for the swiveling, retractable lift engines at a height/diameter ratio of 5.0 . The engines were in the $5^{\circ}$ 
swivel plane and the lift-cruise engine duct extension was installed. Figure Io(a) gives an example of high ingestion (lift engine $\sigma=100^{\circ}$, lift-cruise engine $\sigma=80^{\circ}$ ). The average inlet temperature in the number 2 engine approaches $200^{\circ} \mathrm{F}\left(\triangle T=125^{\circ}\right)$ during engine stall and backfire. The distortion index at stall is approximately 0.2. Results in figure 10(b) are for a configuration at the same ground height with low ingestion. In this figure the lift-engine swivel angle was $70^{\circ}$ while the lift-cruise engine exhaust was vectored $80^{\circ}$. The average temperature rise in both inlets was less than $10^{\circ}$ for the first 6 seconds after maximum RPM was reached; the maximum average temperature rise was less than $20^{\circ}$ for the entire run; and the distortion index was less than 0.1 .

The lift-cruise engines experienced very few stalls with and without the duct extension regardless of lift-engine vector angle. The wing apparently offered sufficient protection for the lift-cruise engine inlets. The duct did, however, act as a mixing chamber for the air entering the lift-cruise engines. Figure 11 presents the average temperature and temperature distortion index at the duct inlet and at the compressor face of the left-hand lift-cruise engine. The lift engines were swiveled to $100^{\circ}$ and the liftcruise engine exhaust was vectored to $90^{\circ}$. Distortion levels above 0.1 were measured at the duct inlet while the maximum distortion level measured at the compressor face was approximately 0.08 . Average inlet temperatures at both the duct inlet and the compressor face were approximately equal with a measured maximum average temperature rise of approximately $20^{\circ} \mathrm{F}$.

The effect of exhaust gas vectoring on available hover lift is shown in figure 12. The results presented are for a height/diameter ratio of 5.0; however, similar results differing only in magnitude could be presented for other ground heights tested. The average inlet temperature increase of approximately $60^{\circ}$ shown for the engines at $90^{\circ}$ swivel angle represents a thrust loss on the order of 25 percent for the $J 85$ engine, as thrust deteriorates at a rate of over 4 percent for each $10^{\circ}$ increase in average inlet temperature (based on 585 manufacturer's performance manual). As the engines were swiveled away from $90^{\circ}$, the inlet temperature rise decreased rapidly causing a corresponding decrease in thrust loss until at $70^{\circ}$ swivel angle little or no thrust degradation was measured. The lift-thrust ratio shown was based on temperature measurements only and does not include induced aerodynamic effects. The vector angle for maximum lift is $70^{\circ}$ to $80^{\circ}$ rather than vertical, because the temperature rise causes $1-\cos \sigma$ to be small in relation to the thrust loss. For a configuration such as the swiveling, retractable lift-engine fighter model, even if the engines can be designed to tolerate the temperature increase shown for vertical engine operation without stalling, this exhaust would be vectored to avoid the thrust loss due to the temperature increase.

Figures 13 and 14 show time temperature histories for the intexnally fixed lift engines with the bifurcated exit.nozzles. Figure 13(a) shows that the number 1 engine stalled on acceleration. Temperature gradients of $500^{\circ}$ /second were measured with an average inlet temperature rise of $26^{\circ}$. Calculated maximum temperature gradients were $1450 \%$ second with an average inlet temperature rise of $44^{\circ}$. Temperature gradients and average inlet 
temperature rise at the time of stall are somewhat lower than in preceding examples. Approximately three quarters of a second before the stall the engine did ingest hot gases, and temperature gradients of $1000^{\circ} /$ second were measured with an average inlet temperature rjse of $60^{\circ}$ across the inlet. The compressor probably could not adjust to the intermittent ingestion during acceleration thereby causing the stall. Intermittent reingestion occurred in the number 2 engine for approximately 15 seconds after the number 1 engine stalled; then the compressor stalled. The measured average temperature rise and maximum temperature gradients at stall were $70^{\circ}$ and $900^{\circ} /$ second, respectively. When corrected, these values became $173^{\circ}$ and $1750^{\circ} /$ second.

During the acceleration prior to stall on the number 1 engine, the position of the exhaust gas fountain caused the number 1 compressor to ingest hot gas and to stall, but very minor ingestion was recorded in the number 2 inlet. Shortly after the number 1 engine stalled, however, the fountain shifted aft and ingestion in varying amounts occurred in the number 2 engine until the compressor stalled. Measured ingestion with the engine exhaust vectored to $75^{\circ}$ was minor (fig. 14). Reingestion was not measurable for the first 8 seconds as shown by the average $\triangle T$ trace for the three lift engines and the left-hand lift-cruise engine. This time interval should be adequate for takeoff but might not be sufficient for the landing phase because to land the aircraft would have to settle through a cloud of hot exhaust gas.

As with the swiveling, retractable configuration, exhaust-gas vectoring was the most effective means of reducing or eliminating ingestion and the attendant thrust loss for the internally fixed lift-engine configuration. Results with exhaust gas vectoring are shown in figure 15 for the three exit nozzles used. The effect of doors on the bottom of the fuselage is also shown for the conical and slotted exit nozzles. It was not possible to operate the engines stall free at $80^{\circ}$ and $90^{\circ}$ with the three exit nozzles tested; furthermore, with the conical nozzles, the engines could not be accelerated to 100 percent RPM before stalling. Other results shown on the figure were taken prior to engine stall but after reaching 100 percent RPM. Higher temperatures were measured with the slotted nozzles at $80^{\circ}$ than at $90^{\circ}$. The reason for this is not known. The reingestion level was lower with the slotted nozzles than with either the bifurcated or conical nozzles at all ground positions tested. The simulated doors along the bottom of the fuselage were beneficial in lowering the measured $\Delta \mathrm{T}$. Depending on the type of vectoring system used, docrs along the bottom of the fuselage that could be used to seal the bottom of the fuselage during conventional flight could, if properly placed, be effective in reducing the magnitude of the temperature increase.

Figure 16 is a general summary of the ingestion results obtained for both the swiveling, retractable and internally fixed lift-engine configurations (taken from table 1) showing the effects of exhaust gas vectoring. Only the exhaust from the swiveling, retractable configuration could be vectored forward $\left(90^{\circ}\right.$ to $\left.110^{\circ}\right)$. Of the four ground heights tested $(2.5,5.0,7.5$, and 9.7), 5 and 7.5 were the worst for ingestion. Results shown are general and are for no wind. The engine cant angle for the swiveling, retractable lift engines was $15^{\circ}$; however, the results at $0^{\circ}$ show similar characteristics. Of 
the three exhaust nozzles tested with the internally fixed lift engines, the slotted nozzles produced somewhat lower temperature gradients and average inlet temperatures than the conical or bifurcated nozzles; however, with the exhaust at angles of $80^{\circ}$ and $90^{\circ}$, the engines stalled regardless of exhaust nozzle installation.

Although no forward vectoring $\left(90^{\circ}\right.$ to $\left.110^{\circ}\right)$ was accomplished with the internally fixed configuration because of a limitation in the thrust vectoring system, there is no reason to believe the results (because of the similarity between $70^{\circ}$ and $90^{\circ}$ ) would be different from those shown for the swiveling, retractable configuration.

Proper vectoring of the lift engines forward and lift-cruise engines aft to balance moment, provided adequate thrust to weight ratios are available, should provide VTOL capability to both configurations.

\section{Inlet Performance in Transition}

Inlet flow distortion and pressure recovery are of primary concern along with exhaust gas reingestion for aircraft using lift engines for VTOL maneuvering. Flow distortion and inlet recovery were studied in the Ames $40-$ by 80-Foot Wind Tunnel during transition from hover to wing-supported flight for both lift-engine configurations.

Swiveling, retractable configuration- A particular advantage of the swiveling, ratractable configuration is that engine starting and acceleration at the beginning of a decelerating transition will not impose a severe inlet design condition on the lift engines. The engines can be rotated into the airstream at the beginning of the transition for starting, thereby eliminating the high crossflow angle and the necessity of the inlet decelerating the crossflow and turning this flow $90^{\circ}$. Once started, the engines can be accelerated and rotated toward the vertical position as the transition proceeds.

The effect of inlet velocity ratio (the ratio of free stream to inlet velocity) on distortion and pressure recovery is shown in figure 17 for engine angles of $90^{\circ}$ and $75^{\circ}$. Maximum inlet distortion is less than 4 percent with inlet pressure recovery greater than 0.995. As the engines were swiveled toward horizontal, inlet distortion decreased until at an engine angle of $30^{\circ}$ there was little measurable distortion. The effect of angle of attack is shown in figure 18 for engine angles of $90^{\circ}$ and $75^{\circ}$. The variation in distortion and loss in total-pressure recovery are more pronounced at $75^{\circ}$ than at 90\%. A noticeable increase in distortion occurred in the number 1 inlet at angles of attack between $4^{\circ}$ and $8^{\circ}$. The effect of sideslip is shown in figure 19 for engine angles of $75^{\circ}, 60^{\circ}$, and $45^{\circ}$ at $0^{\circ}$ angle of attack. The variation in distortion and loss in total-pressure recovery is negligible for the sideslip range shown.

These results indicate that the inlet used (fig. 4(a)) was acceptable throughout the range of inlet velocity ratios and engine angles tested during transition. Distortion levels are within acceptable limits for the J-85 engine (less than 10 percent). 
Internally fixed configuration- The effect of velocity ratio on inlet distortion and pressure recovery with and without the inlet guide vanes is shown in figure 20. Comparison shows that at the higher velocity ratios ( 1.6 to 1.8 ) the inlet guide vane decreased the distortion level approximately 2 percent. At a velocity ratio of 1.8 (corresponding to 150 knots forward speed with the engines at idle thrust) without the inlet guide vanes, the distortion level is at the manufacturer's recommended nominal limit of 10 percent.

The results from reference 1 are compared in figure 21 with the results of this investigation. The inlets of reference 1 were tilted forward of vertical, as shown on the figure, allowing a generous leading-edge inlet radius ( 0.56 radius to inlet diameter ratio). The engines of the present investigation were mounted vertically. The inlet radius to diameter ratio was 0.19 . The results of reference 1 show, as expected, somewhat better pressure recovery and slightly lower distortion levels at the high velocity ratios; however, the distortion levels from both investigations were below the nominal acceptable level of 10 percent.

The variation in distortion and inlet recovery with angle of attack is shown in figure 22 for a velocity ratio of approximately 1.8 . With the inlet guide vane installed the variation in distortion level and inlet recovery was negligible. Without the inlet guide vane the distortion level was approximately 2 percent higher and the variation more pronounced. Without the guide vane, the nominal acceptable distortion level of 10 percent for the J-85 engine was approached or exceeded regardless of angle of attack. Similar trends are shown when sideslip angle was varied. With the inlet guide vane installed, distortion and recovery levels are fairly constant; without the guide vane, distortion levels are on the order of 2 percent higher and recovery is reduced (fig. 23). As with angle of attack, the variation in distortion was more pronounced without the guide vane.

CONCLUDING REMARKS

The configuration tested experienced excessive thrust loss and compressor stalls when the thrust was vectored $90^{\circ}$ from horizontal; therefore, vertical engine operation on such a configuration does not appear feasible. Even if engines can be built to withstand temperature rise and temperature distortion of the magnitude shown, the loss in thrust attendant with the temperature rise would greatly reduce VTOL performance. VTOL operation appears promising if the lift engines are vectored forward and the lift-cruise engine exhaust is vectored aft to balance the aircraft and alleviate exhaust-gas reingestion. The aircraft could then take off and land within an area surrounded by hot exhaust but would be relatively free of ingestion effects.

Inlet flow distortion and total-pressure recovery were within acceptable limits for the swiveling, retractable configuration with J85 engines. Placing a circular inlet vane on the 0.19 radius inlet of the internally fixed lift engine was beneficial in turning the flow into the vertically mounted lift 
engines at the higher velocity ratios. The guide vane also reduced distortion levels about 2 percent (with angles of attack and sideslip) and allowed adequate stall margin at the higher velocity ratios.

Ames Research Center National Aeronautics and Space Administration Moffett Field, Calif., 94035, July 23, 1970

REFERENCES

1. Tolhurst, William H.; and Kelly, Mark W.: Characteristics of Two Large-Scale Jet-Lift Propulsion Systems. NASA SP-116, Paper 15, 1966.

2. Lavi, R.: An Experimental Investigation of a VTOL Lift-Engine Inlet. J. Aircraft, vol. 4, no. 2, March-April 1967.

3. Tyson, B. I.: Tests to Establish Flow Distortion Criteria for Lift Engines. J. Aircraft, vol. 2, no. 5, Sept. - Oct. 1965.

4. Lavi, R.; Hall, G. R.; and Stark, W. W.: Full-Scale Ground Proximity Investigation of a VTOL Fighter Model Aircraft. NASA CR-1098, 1968. 
(a) Swiveling, retractable configuration; $20^{\circ}$ swivel plane; no lift-cruise duct extension

\begin{tabular}{|c|c|c|c|c|c|c|c|c|}
\hline & \multicolumn{4}{|c|}{$\eta=0^{\circ}$} & \multicolumn{4}{|c|}{$\eta=15^{\circ}$} \\
\hline$\frac{\mathrm{H}}{\mathrm{D}}$ & $\begin{array}{l}\sigma_{I}=70^{\circ} \\
\sigma_{C}=70^{\circ}\end{array}$ & $\begin{array}{l}\sigma_{I}=80^{\circ} \\
\sigma_{C}=80^{\circ}\end{array}$ & $\begin{array}{l}\sigma_{L}=90^{\circ} \\
\sigma_{C}=90^{\circ}\end{array}$ & $\begin{array}{l}\sigma_{L}=100^{\circ} \\
\sigma_{C}=80^{\circ}\end{array}$ & $\begin{array}{l}\sigma_{I_{L}}=70^{\circ} \\
\sigma_{\mathrm{C}}=65.4^{\circ}\end{array}$ & $\begin{array}{l}\sigma_{L}=80^{\circ} \\
\sigma_{C}=72^{\circ}\end{array}$ & $\begin{array}{l}\sigma_{\mathrm{L}}=90^{\circ} \\
\sigma_{\mathrm{C}}=75^{\circ}\end{array}$ & $\begin{array}{l}\sigma_{I}=100^{\circ} \\
\sigma_{C}=72.3^{\circ}\end{array}$ \\
\hline 9.7 & $\begin{array}{l}\text { Stall } \\
\text { free } \\
\text { Ingestion } \\
\text { free }\end{array}$ & $\begin{array}{l}\text { Stall } \\
\text { free } \\
\text { Ingestion } \\
\text { free }\end{array}$ & & & $\begin{array}{l}\text { Stall } \\
\text { free } \\
\text { Ingestion } \\
\text { free }\end{array}$ & $\begin{array}{l}\text { Stall } \\
\text { free } \\
\text { Ingestion } \\
\text { light }\end{array}$ & $\begin{array}{l}\text { Stall } \\
\text { free } \\
\text { Ingestion } \\
\text { moderate } \\
\text { to heavy } \\
\end{array}$ & $\begin{array}{l}\text { Stall } \\
\text { engine } 4\end{array}$ \\
\hline 7.5 & & $\begin{array}{l}\text { Stall } \\
\text { free } \\
\text { Ingestion } \\
\text { light }\end{array}$ & $\begin{array}{l}\text { Stall } \\
\text { engines } \\
4 \text { and } 3\end{array}$ & & $\begin{array}{l}\text { Stall } \\
\text { free } \\
\text { Ingestion } \\
\text { free }\end{array}$ & $\begin{array}{l}\text { Stall } \\
\text { free } \\
\text { Ingestion } \\
\text { light }\end{array}$ & $\begin{array}{l}\text { Stall } \\
\text { engine } 4\end{array}$ & $\begin{array}{l}\text { Stall } \\
\text { engine } 4\end{array}$ \\
\hline 5.0 & $\begin{array}{l}\text { Stall } \\
\text { free } \\
\text { Ingestion } \\
\text { light }\end{array}$ & $\begin{array}{l}\text { Stall } \\
\text { free } \\
\text { Ingestion } \\
\text { light to } \\
\text { moderate }\end{array}$ & $\begin{array}{l}\text { Stall } \\
\text { engines } \\
4,3 \text {, and } \\
2\end{array}$ & & $\begin{array}{l}\text { Stall } \\
\text { free } \\
\text { Ingestion } \\
\text { light }\end{array}$ & $\begin{array}{l}\text { Stall } \\
\text { engine } 4\end{array}$ & $\begin{array}{l}\text { Stall } \\
\text { engine } 4\end{array}$ & $\begin{array}{l}\text { Stall } \\
\text { free } \\
\text { Ingestion } \\
\text { moderate } \\
\text { to heavy }\end{array}$ \\
\hline 2.5 & $\begin{array}{l}\text { Stall } \\
\text { free } \\
\text { Ingestion } \\
\text { free }\end{array}$ & $\begin{array}{l}\text { Stall } \\
\text { free } \\
\text { Ingestion } \\
\text { moderate }\end{array}$ & $\begin{array}{l}\text { Stall } \\
\text { Iree } \\
\text { Ingestion } \\
\text { heavy }\end{array}$ & $\begin{array}{l}\text { Stall } \\
\text { Iree } \\
\text { Ingestion } \\
\text { moderate }\end{array}$ & $\begin{array}{l}\text { Stall } \\
\text { free } \\
\text { Ingestion } \\
\text { light }\end{array}$ & $\begin{array}{l}\text { Stall } \\
\text { free } \\
\text { Ingestion } \\
\text { free }\end{array}$ & $\begin{array}{l}\text { Stall } \\
\text { free } \\
\text { Ingestion } \\
\text { moderate } \\
\text { to heavy }\end{array}$ & $\begin{array}{l}\text { Stall } \\
\text { engine } 4\end{array}$ \\
\hline
\end{tabular}


TABLE 1.- INGESTION SUMMARY FOR THE LIFT-EINGINE FIGITERR MODEL - Continued

(b) Swiveling, retractable configuration; $5^{\circ}$ swivel plane; lift-cruise duct extension

\begin{tabular}{|c|c|c|c|c|c|c|c|c|}
\hline \multicolumn{9}{|c|}{$\eta=0^{\circ}$} \\
\hline$\frac{\mathrm{H}}{\mathrm{D}}$ & $\begin{array}{l}\sigma_{L}=70^{\circ} \\
\sigma_{C}=70^{\circ}\end{array}$ & $\begin{array}{l}\sigma_{L}=75^{\circ} \\
\sigma_{C}=70^{\circ}\end{array}$ & $\begin{array}{l}\sigma_{I}=75^{\circ} \\
\sigma_{C}=80^{\circ}\end{array}$ & $\begin{array}{l}\sigma_{L}=80^{\circ} \\
\sigma_{C}=80^{\circ}\end{array}$ & $\begin{array}{l}\sigma_{\mathrm{L}}=90^{\circ} \\
\sigma_{\mathrm{C}}=70^{\circ}\end{array}$ & $\begin{array}{l}\sigma_{L}=90^{\circ} \\
\sigma_{C}=80^{\circ}\end{array}$ & $\begin{array}{l}\sigma_{\mathrm{I}}=100^{\circ} \\
\sigma_{\mathrm{C}}=80^{\circ}\end{array}$ & $\begin{array}{l}\sigma_{I}=110^{\circ} \\
\sigma_{C}=70^{\circ}\end{array}$ \\
\hline 9.7 & $\begin{array}{l}\text { Stall } \\
\text { free } \\
\text { Ingestion } \\
\text { light }\end{array}$ & $\begin{array}{l}\text { Stall } \\
\text { free } \\
\text { Ingestion } \\
\text { light to } \\
\text { moderate }\end{array}$ & $\begin{array}{l}\text { Stall } \\
\text { free } \\
\text { Ingestion } \\
\text { light to } \\
\text { moderate }\end{array}$ & $\begin{array}{l}\text { Stall } \\
\text { free } \\
\text { Ingestion } \\
\text { light to } \\
\text { moderate }\end{array}$ & & $\begin{array}{l}\text { Stall } \\
\text { engines } \\
2,3,4, \\
\text { and } 6\end{array}$ & $\begin{array}{l}\text { Stall } \\
\text { free } \\
\text { Ingestion } \\
\text { moderate } \\
\text { to heavy }\end{array}$ & $\begin{array}{l}\text { Stall } \\
\text { free } \\
\text { Ingestion } \\
\text { light }\end{array}$ \\
\hline 7.5 & $\begin{array}{l}\text { Stall } \\
\text { free } \\
\text { Ingestion } \\
\text { free }\end{array}$ & $\begin{array}{l}\text { Stal1 } \\
\text { engine } 4\end{array}$ & $\begin{array}{l}\text { Stall } \\
\text { engine } 2\end{array}$ & & $\begin{array}{l}\text { Stall } \\
\text { engines } \\
4 \text { and } 2\end{array}$ & & $\begin{array}{l}\text { Stall } \\
\text { engines } \\
I \text { and } 4\end{array}$ & $\begin{array}{l}\text { Stall } \\
\text { free } \\
\text { Ingestion } \\
\text { light }\end{array}$ \\
\hline 5.0 & $\begin{array}{l}\text { StalI } \\
\text { free } \\
\text { Ingestion } \\
\text { light }\end{array}$ & $\begin{array}{l}\text { Stall } \\
\text { free } \\
\text { Ingestion } \\
\text { moderate }\end{array}$ & $\begin{array}{l}\text { Stal1 } \\
\text { engine } 2\end{array}$ & $\begin{array}{l}\text { Stall } \\
\text { engines } \\
2 \text { and } 4\end{array}$ & & & $\begin{array}{l}\text { Stall } \\
\text { engine } 2\end{array}$ & $\begin{array}{l}\text { Stall } \\
\text { free } \\
\text { Ingestion } \\
\text { light }\end{array}$ \\
\hline 2.5 & $\begin{array}{l}\text { Stall } \\
\text { free } \\
\text { Ingestion } \\
\text { light }\end{array}$ & $\begin{array}{l}\text { Stall } \\
\text { free } \\
\text { Ingestion } \\
\text { moderate } \\
\text { to heavy }\end{array}$ & & & & & & \\
\hline
\end{tabular}


(c) Internally fixed configuration

\begin{tabular}{|c|c|c|c|c|c|c|c|c|}
\hline \multicolumn{4}{|c|}{ Slotted nozzles } & \multicolumn{2}{|c|}{ Bifurcated nozzles } & \multicolumn{3}{|c|}{ Conical nozzles } \\
\hline$\frac{\mathrm{H}}{\bar{D}}$ & $\begin{array}{l}\sigma_{L}=70^{\circ} \\
\sigma_{\mathrm{C}}=70^{\circ}\end{array}$ & $\begin{array}{l}\sigma_{L}=80^{\circ} \\
\sigma_{C}=80^{\circ}\end{array}$ & $\begin{array}{l}\sigma_{L}=90^{\circ} \\
\sigma_{\mathrm{C}}=82^{\circ}\end{array}$ & $\begin{array}{l}\sigma_{L}=75^{\circ} \\
\sigma_{\mathrm{C}}=75^{\circ}\end{array}$ & $\begin{array}{l}\sigma_{\perp}=90^{\circ} \\
\sigma_{C}=82^{\circ}\end{array}$ & $\begin{array}{l}\sigma_{L}=70^{\circ} \\
\sigma_{C}=70^{\circ}\end{array}$ & $\begin{array}{l}\sigma_{L}=80^{\circ} \\
\sigma_{C}=80^{\circ}\end{array}$ & $\begin{array}{l}\sigma_{L}=90^{\circ} \\
\sigma_{\mathrm{C}}=82^{\circ}\end{array}$ \\
\hline 9.7 & $\begin{array}{l}\text { Stall } \\
\text { free } \\
\text { Ingestion } \\
\text { light } \\
<6^{\circ} \Delta \mathrm{T}\end{array}$ & $\begin{array}{l}\text { Stall } \\
\text { free } \\
\text { Ingestion } \\
\text { light } \\
<15^{\circ} \Delta \mathrm{T}\end{array}$ & $\begin{array}{l}\text { Stall } \\
\text { engine } 1\end{array}$ & $\begin{array}{l}\text { Stall } \\
\text { free } \\
\text { Ingestion } \\
\text { light } \\
<15^{\circ} \Delta \Gamma\end{array}$ & $\begin{array}{l}\text { Stall } \\
\text { engines } \\
1 \text { and } 2\end{array}$ & $\begin{array}{l}\text { Stall } \\
\text { free } \\
\text { Ingestion } \\
\text { light } \\
<10^{\circ} \triangle \mathrm{T}\end{array}$ & $\begin{array}{l}\text { Stall } \\
\text { free } \\
\text { Ingestion } \\
\text { moderate } \\
\text { to heavy } \\
<90^{\circ} \triangle \mathrm{T}\end{array}$ & $\begin{array}{l}\text { StalI } \\
\text { free } \\
\text { Ingestion } \\
\text { moderate } \\
<30^{\circ} \Delta \mathrm{T}\end{array}$ \\
\hline $7 \cdot 5$ & $\begin{array}{l}\text { Sta.ll } \\
\text { free } \\
\text { Ingestion } \\
\text { light } \\
<5^{\circ} \Delta \mathrm{T}\end{array}$ & $\begin{array}{l}\text { Stall } \\
\text { free } \\
\text { Ingestion } \\
\text { light } \\
<15^{\circ} \Delta \mathrm{T}\end{array}$ & $\begin{array}{l}\text { Stall } \\
\text { free } \\
\text { Ingestion } \\
\text { moderate } \\
<30^{\circ} \Delta \mathrm{T}\end{array}$ & $\begin{array}{l}\text { Stall } \\
\text { free } \\
\text { Ingestion } \\
\text { light to } \\
\text { moderate } \\
<20^{\circ} \triangle T\end{array}$ & $\begin{array}{l}\text { Stall } \\
\text { engine } 1\end{array}$ & $\begin{array}{l}\text { Stall } \\
\text { free } \\
\text { Ingestion } \\
\text { light }\end{array}$ & $\begin{array}{l}\text { Stall } \\
\text { engines } \\
2 \text { and } 1\end{array}$ & $\begin{array}{l}\text { Stall } \\
\text { free } \\
\text { Ingestion } \\
\text { moderate } \\
<35^{\circ} \Delta \mathrm{T}\end{array}$ \\
\hline 5.0 & $\begin{array}{l}\text { Stal1 } \\
\text { free } \\
\text { Ingestion } \\
\text { light } \\
<8^{\circ} \Delta \mathrm{T}\end{array}$ & $\begin{array}{l}\text { Stall } \\
\text { engine I }\end{array}$ & $\begin{array}{l}\text { Stall } \\
\text { Iree } \\
\text { Ingestion } \\
\text { moderate } \\
<35^{\circ} \triangle \mathrm{TT}\end{array}$ & $\begin{array}{l}\text { Stall } \\
\text { free } \\
\text { Ingestion } \\
\text { light to } \\
\text { moderate } \\
<27^{\circ} \triangle \mathrm{T}\end{array}$ & $\begin{array}{l}\text { Sta11 } \\
\text { engines } \\
1 \text { and ? }\end{array}$ & $\begin{array}{l}\text { Stal1 } \\
\text { free } \\
\text { Ingestion } \\
\text { Iight } \\
<10^{\circ} \Delta \mathrm{T}\end{array}$ & $\begin{array}{l}\text { Stall } \\
\text { engines } \\
1 \text { and } 2\end{array}$ & $\begin{array}{l}\text { Stall } \\
\text { engine } 2\end{array}$ \\
\hline 2.5 & $\begin{array}{l}\text { Stall } \\
\text { free } \\
\text { Ingestion } \\
\text { light } \\
<5^{\circ} \triangle \mathrm{T}\end{array}$ & $\begin{array}{l}\text { Stall } \\
\text { engine } 1\end{array}$ & $\begin{array}{l}\text { Stall } \\
\text { free } \\
\text { Ingestion } \\
\text { moderate } \\
<40^{\circ} \Delta T\end{array}$ & $\begin{array}{l}\text { Stall } \\
\text { free } \\
\text { Ingestion } \\
\text { light } \\
<10^{\circ} \Delta \mathrm{T}\end{array}$ & $\begin{array}{l}\text { Stall } \\
\text { engines } \\
1 \text { and } 2\end{array}$ & $\begin{array}{l}\text { Stall } \\
\text { free } \\
\text { Ingestion } \\
\text { light } \\
<15^{\circ} \triangle \mathrm{T}\end{array}$ & $\begin{array}{l}\text { Sta.11 } \\
\text { engines } \\
1 \text { and } 2\end{array}$ & $\begin{array}{l}\text { Stal1 } \\
\text { engine } 1\end{array}$ \\
\hline
\end{tabular}




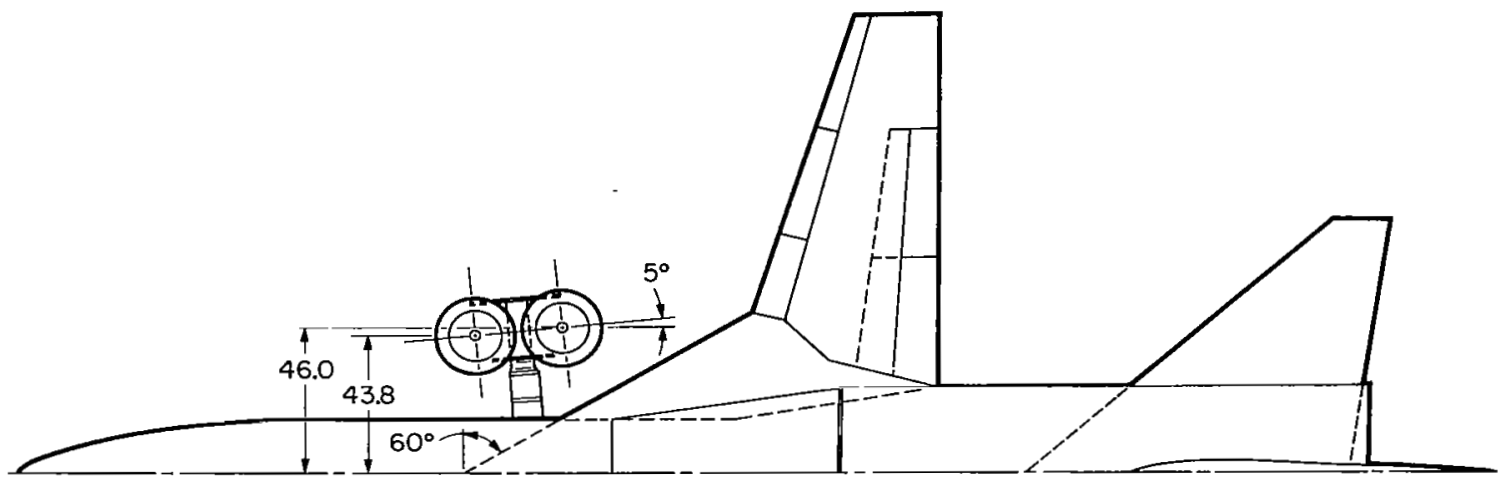

$5^{\circ}$ Swivel plane, lift-cruise engine duct extension

\begin{tabular}{|l|c|c|c|}
\hline & Wing & $\begin{array}{c}\text { Horizontal } \\
\text { toil }\end{array}$ & $\begin{array}{c}\text { Ver tical } \\
\text { tail }\end{array}$ \\
\hline Aspect ratio & 5.82 & 2.87 & .843 \\
\hline $\begin{array}{l}\text { Taper ratio } \\
\text { Area (Ref.) } \\
\text { Airfoil section }\end{array}$ & $\frac{.356}{69-4 \mathrm{ft}^{2}}$ & .182 & .394 \\
\hline
\end{tabular}
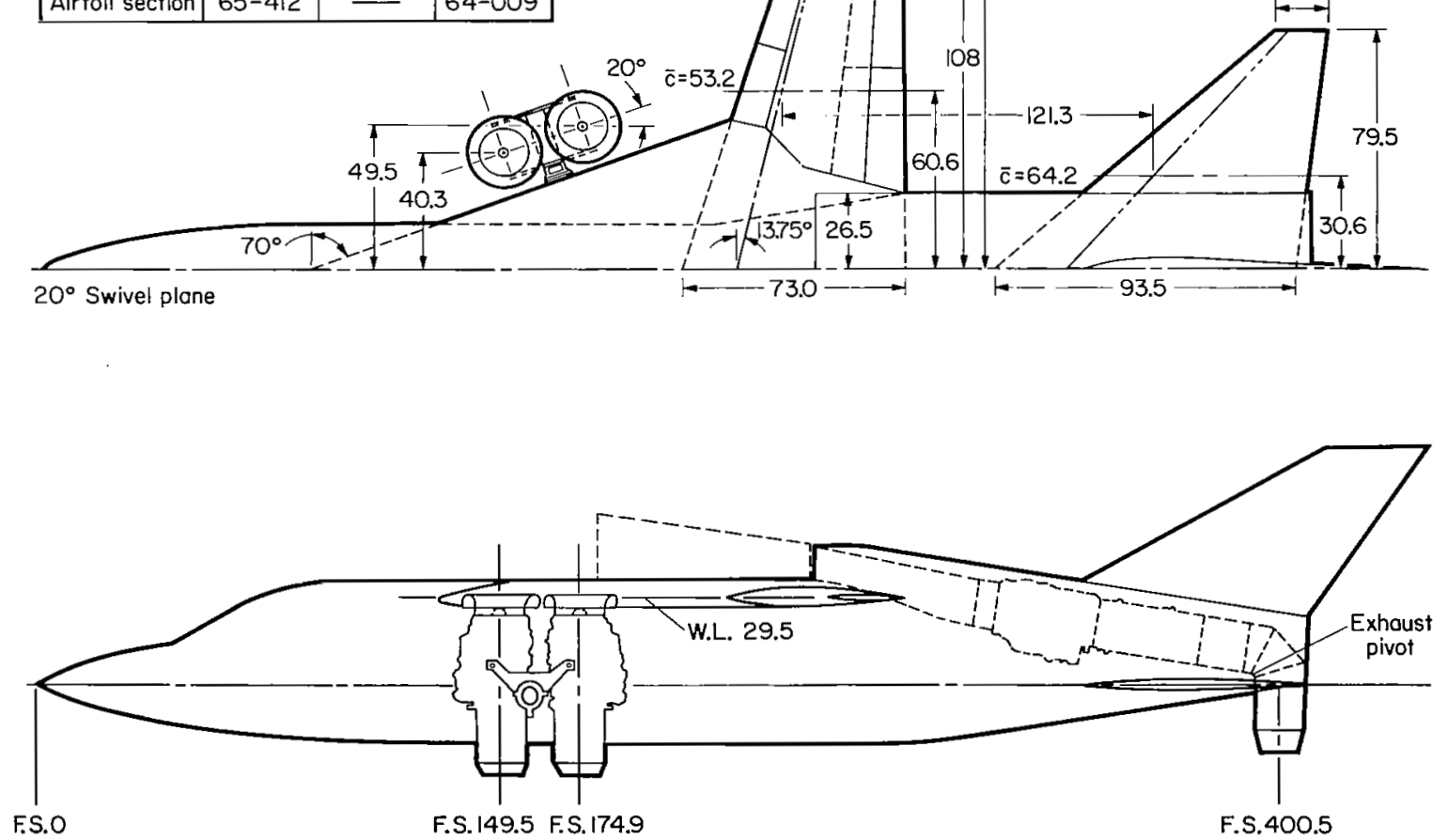

Figure 1.-General arrangement of the swiveling, retractable configuration. 

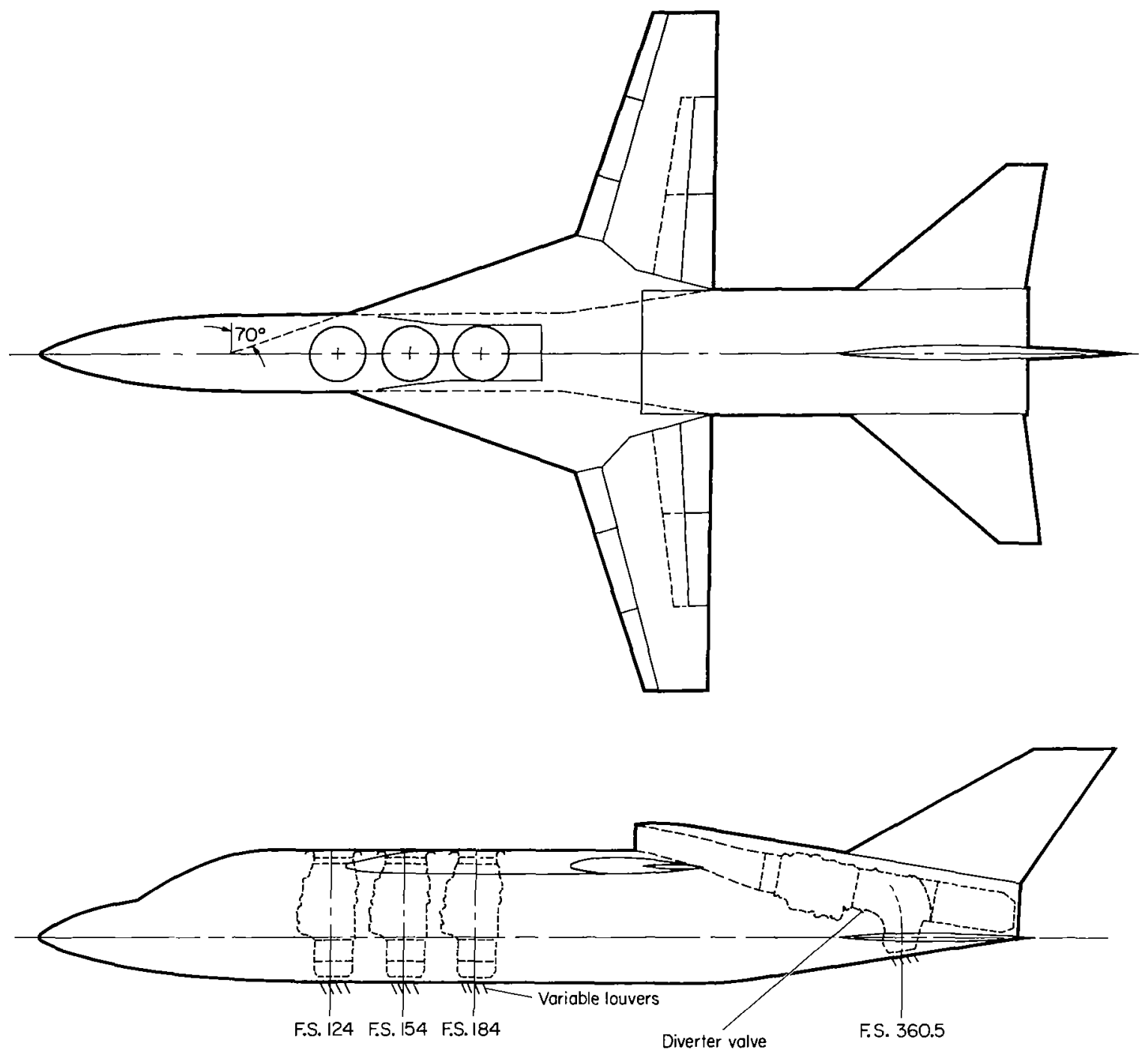

Figure 2.- General arrangement of the internally fixed configuration. 

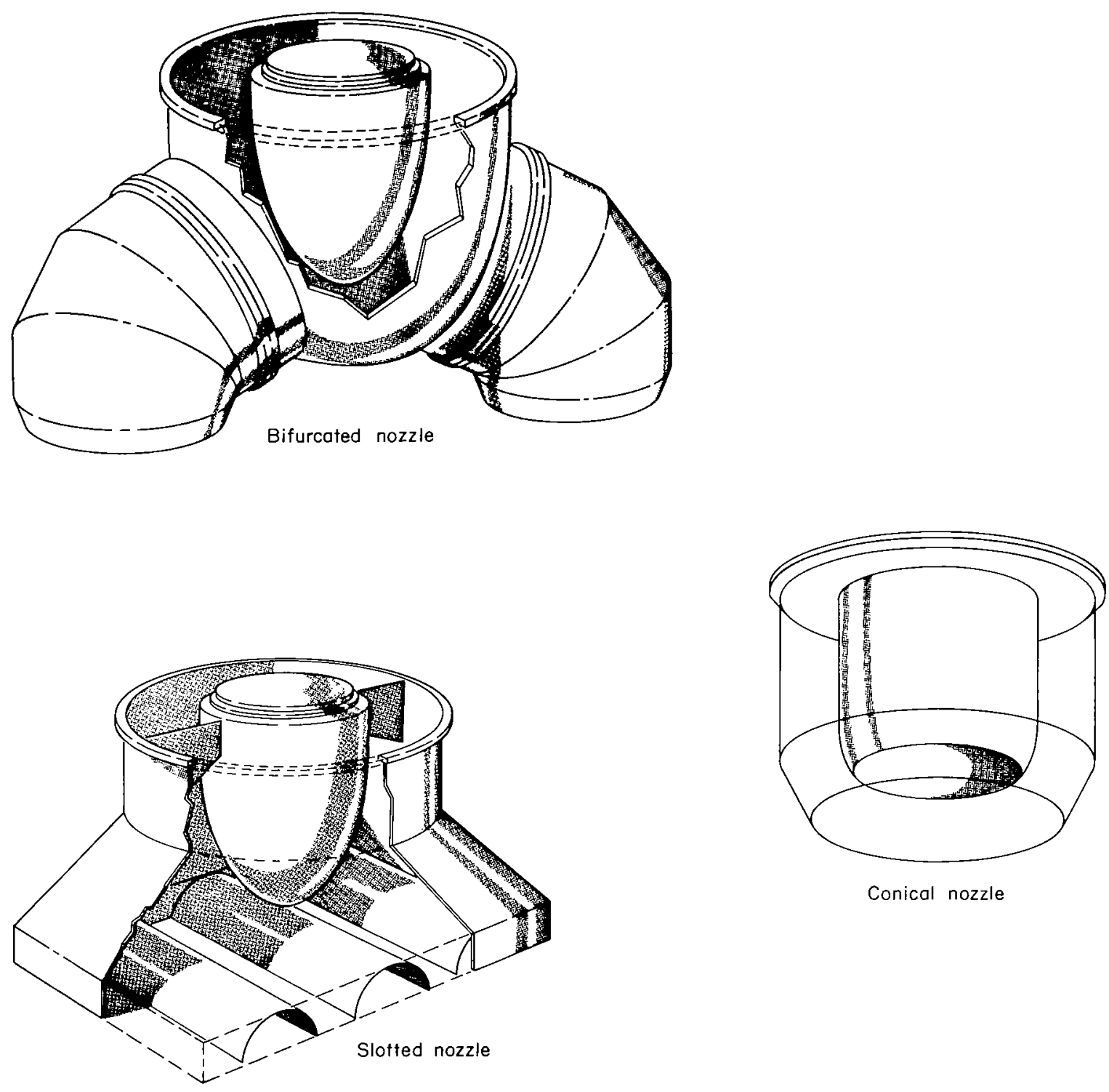

Figure 3.- Lift-engine exit nozzles tested with the internally fixed configuration. 

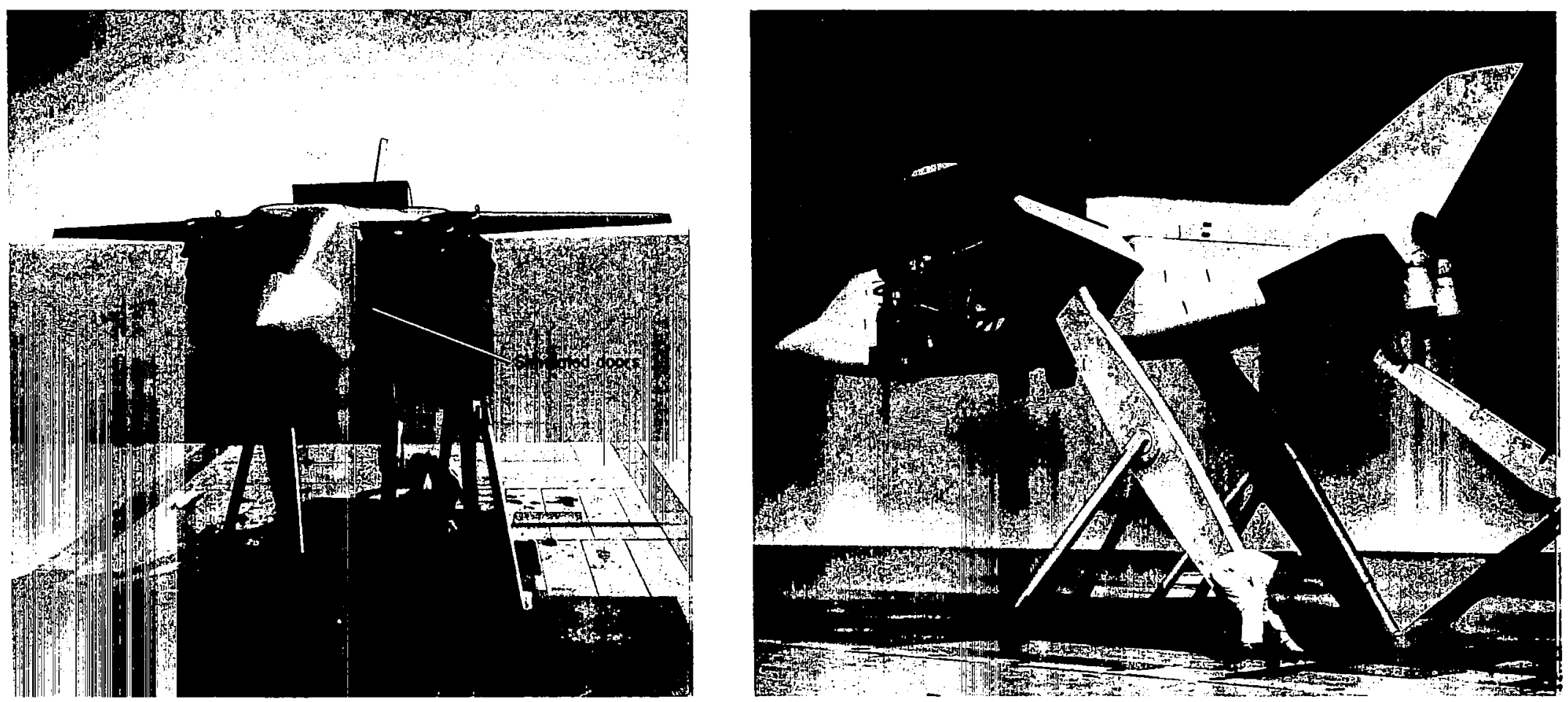

(a) Swiveling, retractable configuration on static test stand.

Figure 4.- Photographs of the model mounted on the Ames static test facility in the 40- by 80 -foot wind tunnel. 

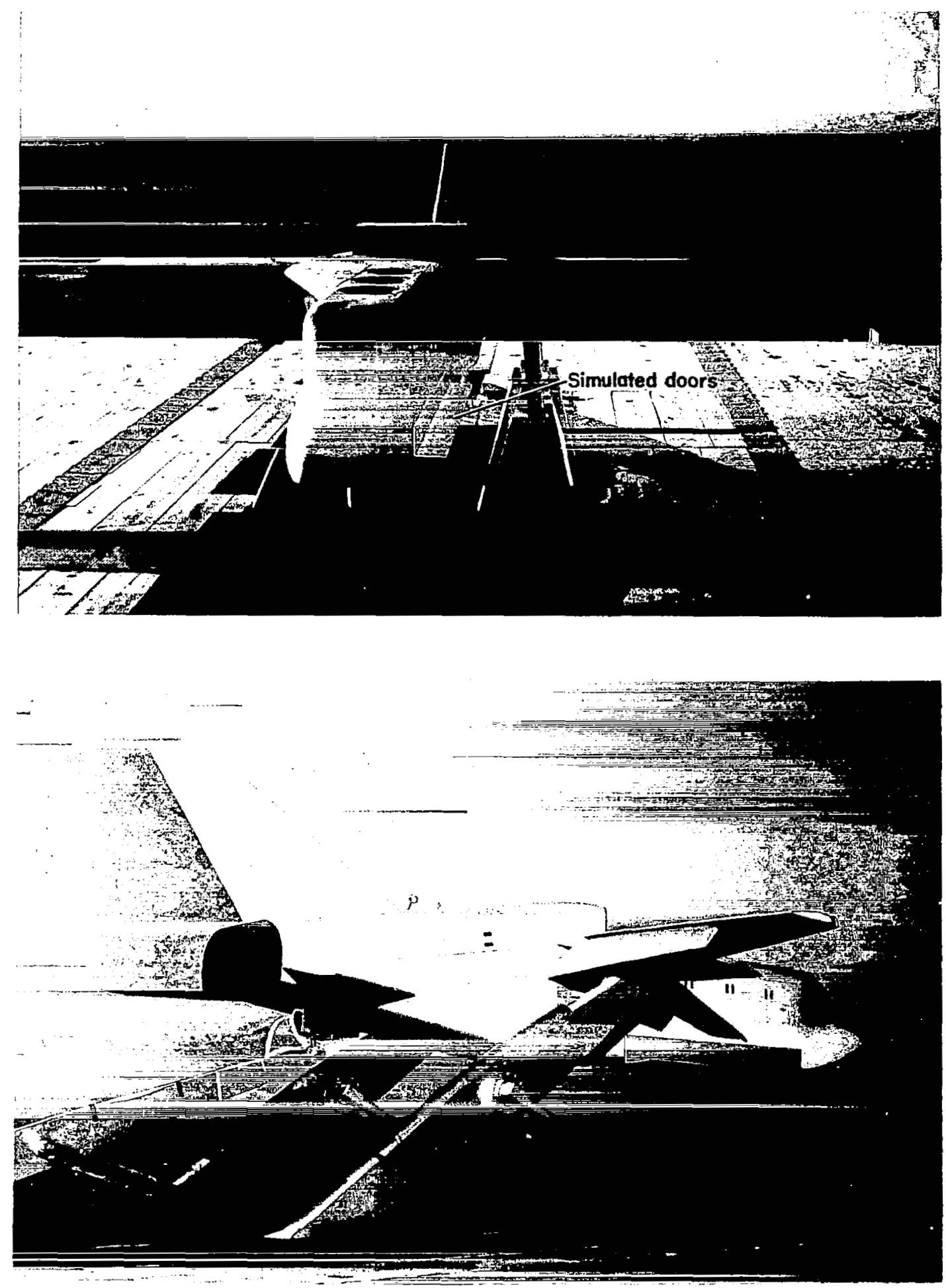

(b) Internally fixed configuration on static test stand. Figure 4.- Continued. 

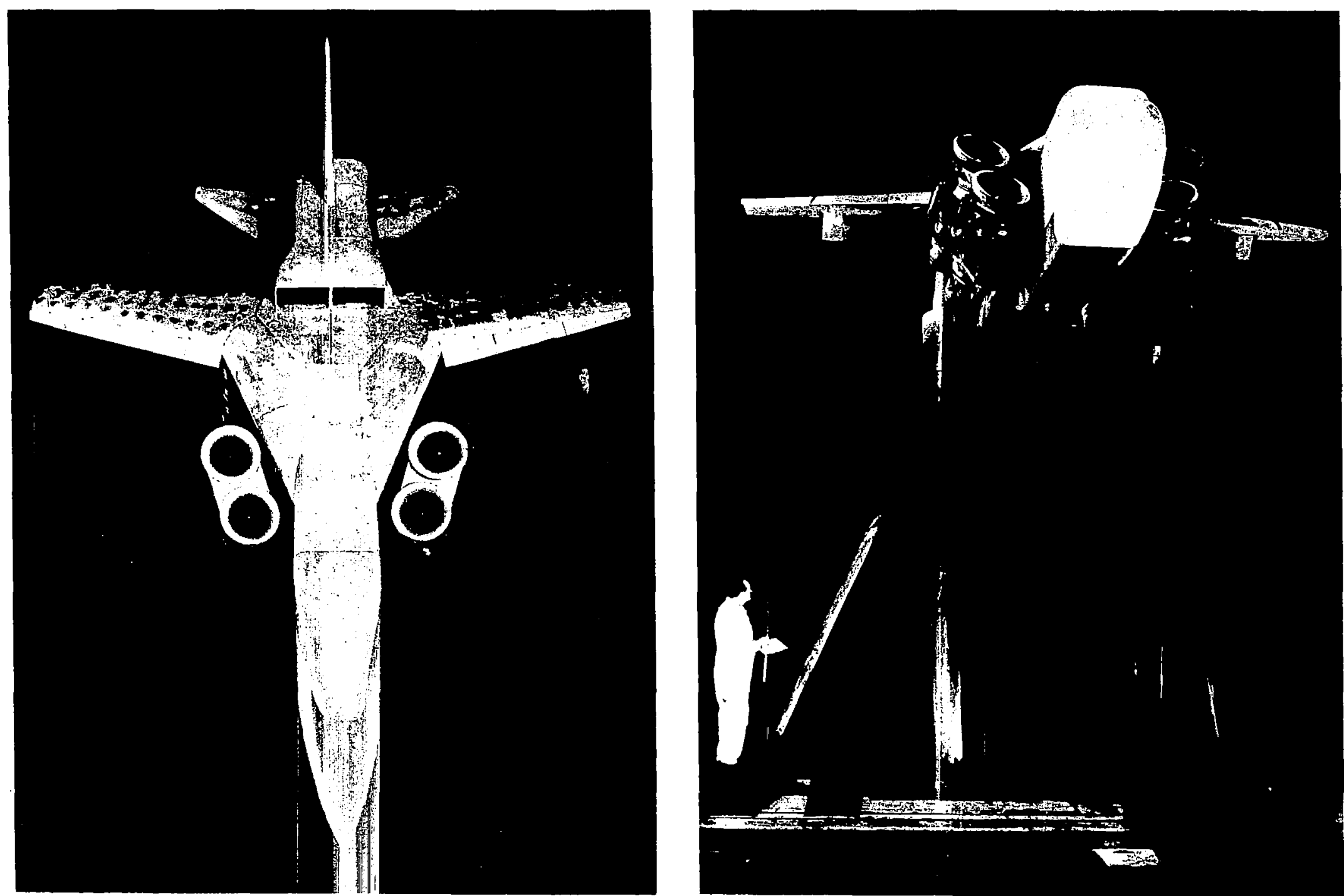

(c) Swiveling, retractable configuration in $40-$ by 80 -foot wind tunnel. Figure 4.- Continued. 


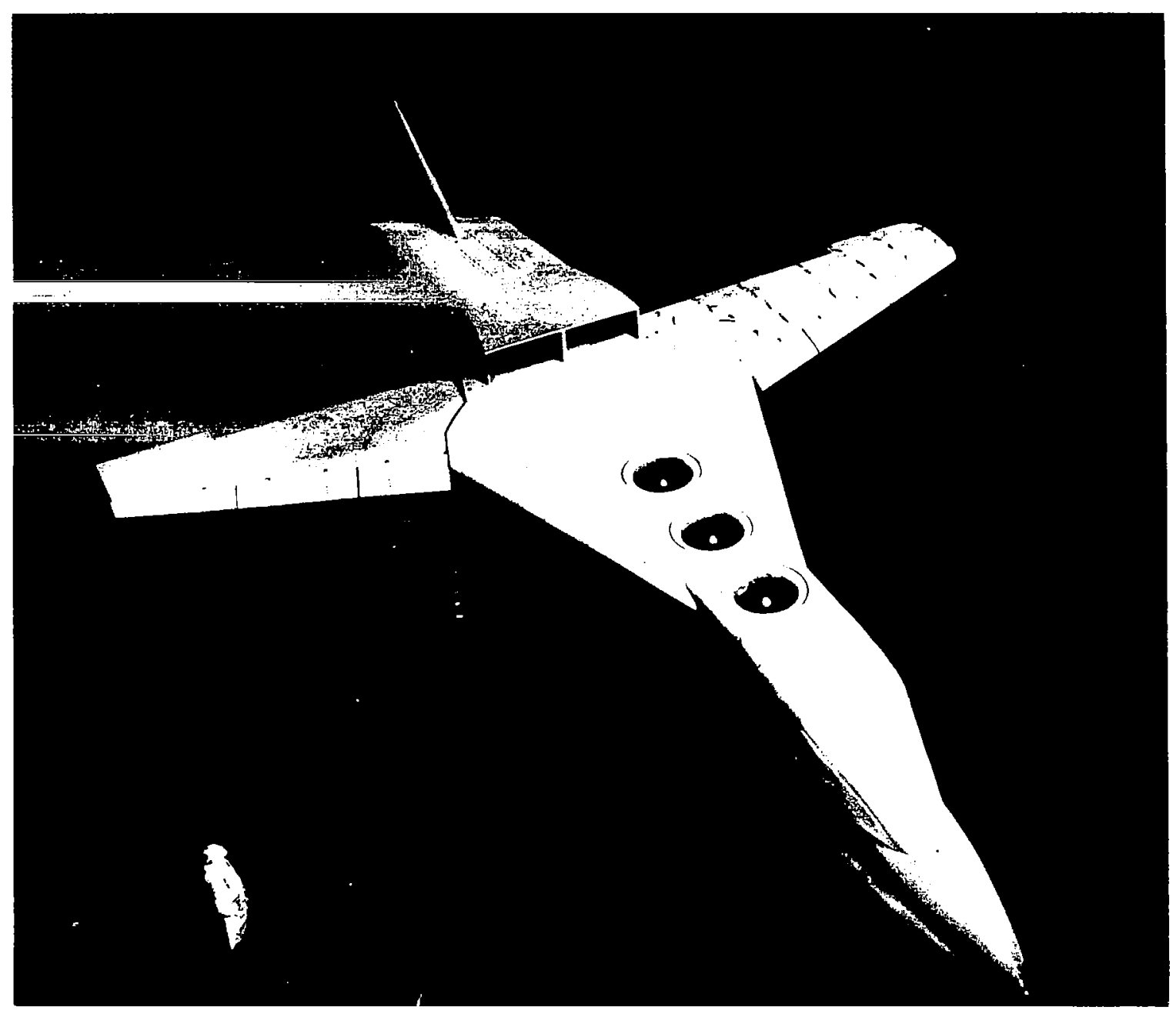

(d) Internally fixed configuration in $40-$ by 80 -foot wind tunnel. Figure 4.- Concluded. 


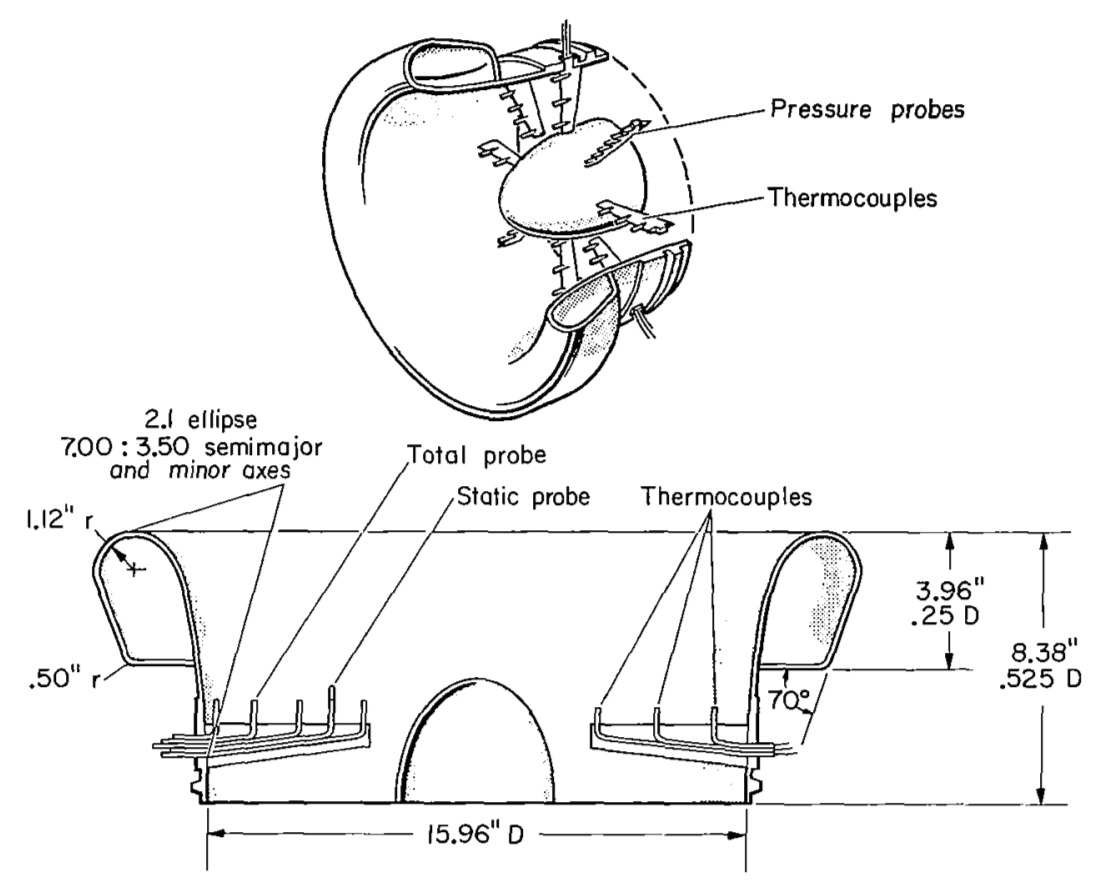

(a) Swiveling, retractable inlet.

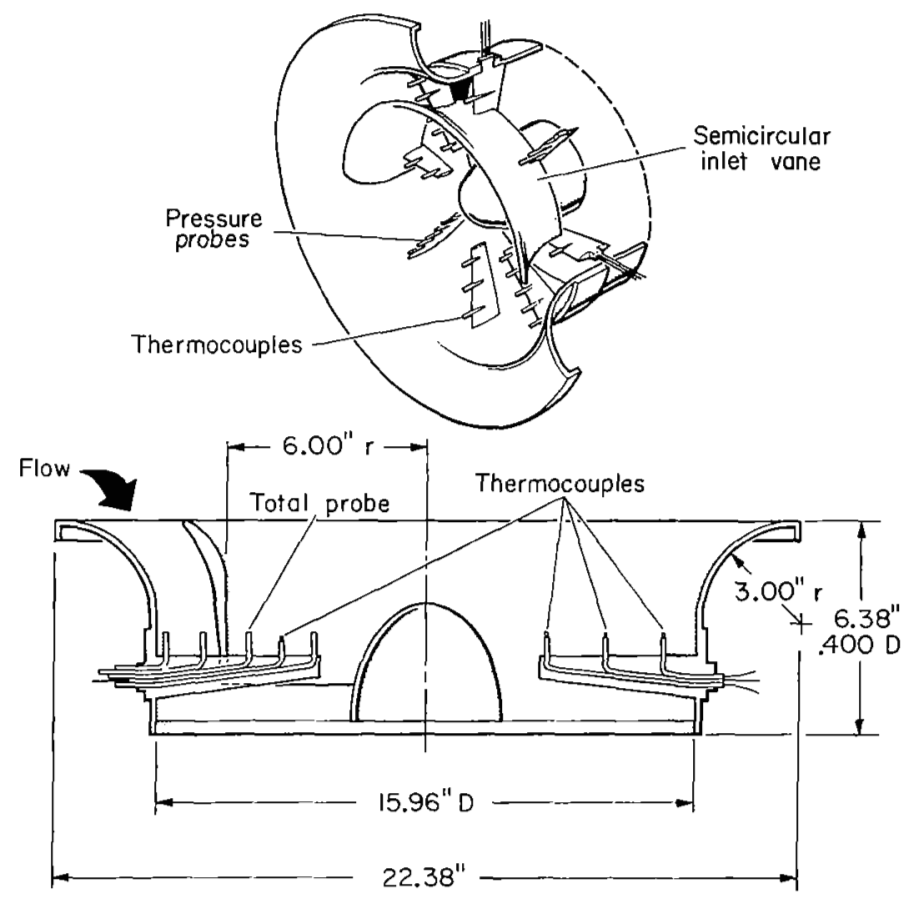

(b) Internally fixed inlet.

Figure 5.- Iift-engine inlet geometry for both configurations. 


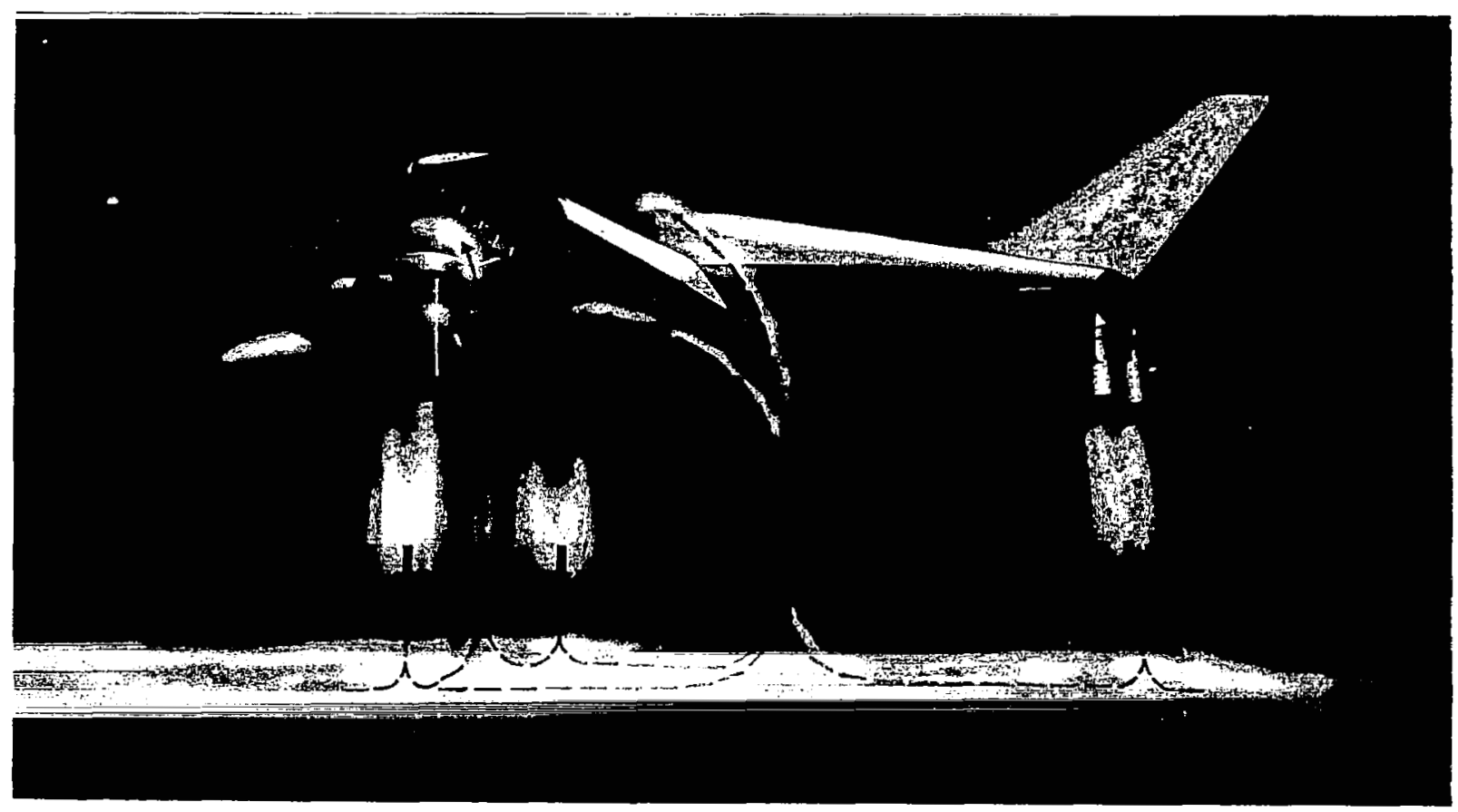

(a) Swiveling, retractable configuration.

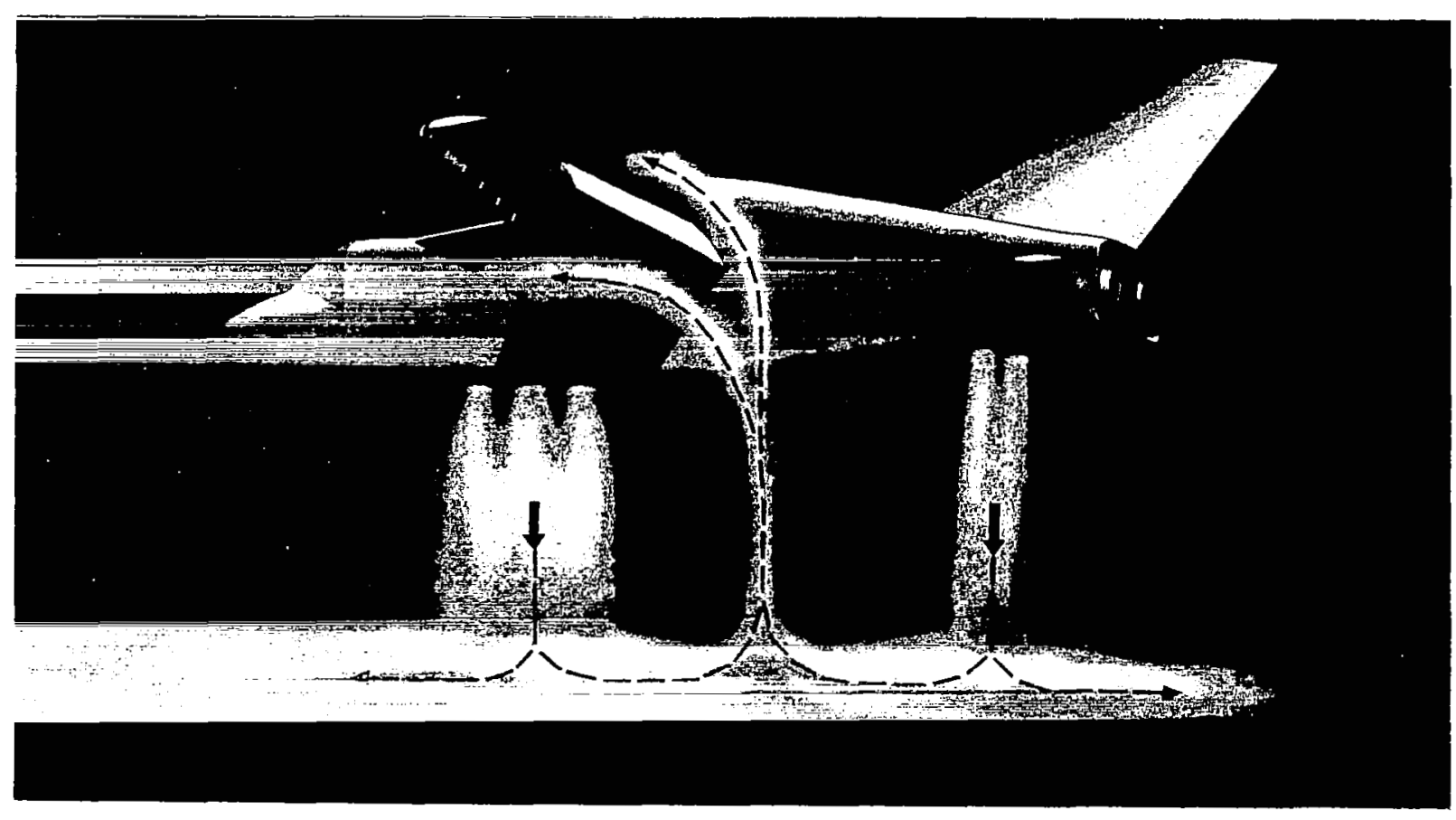

(b) Internally fixed configuration.

Figure 6.- Short-path, high-temperature rise flow patterns. 

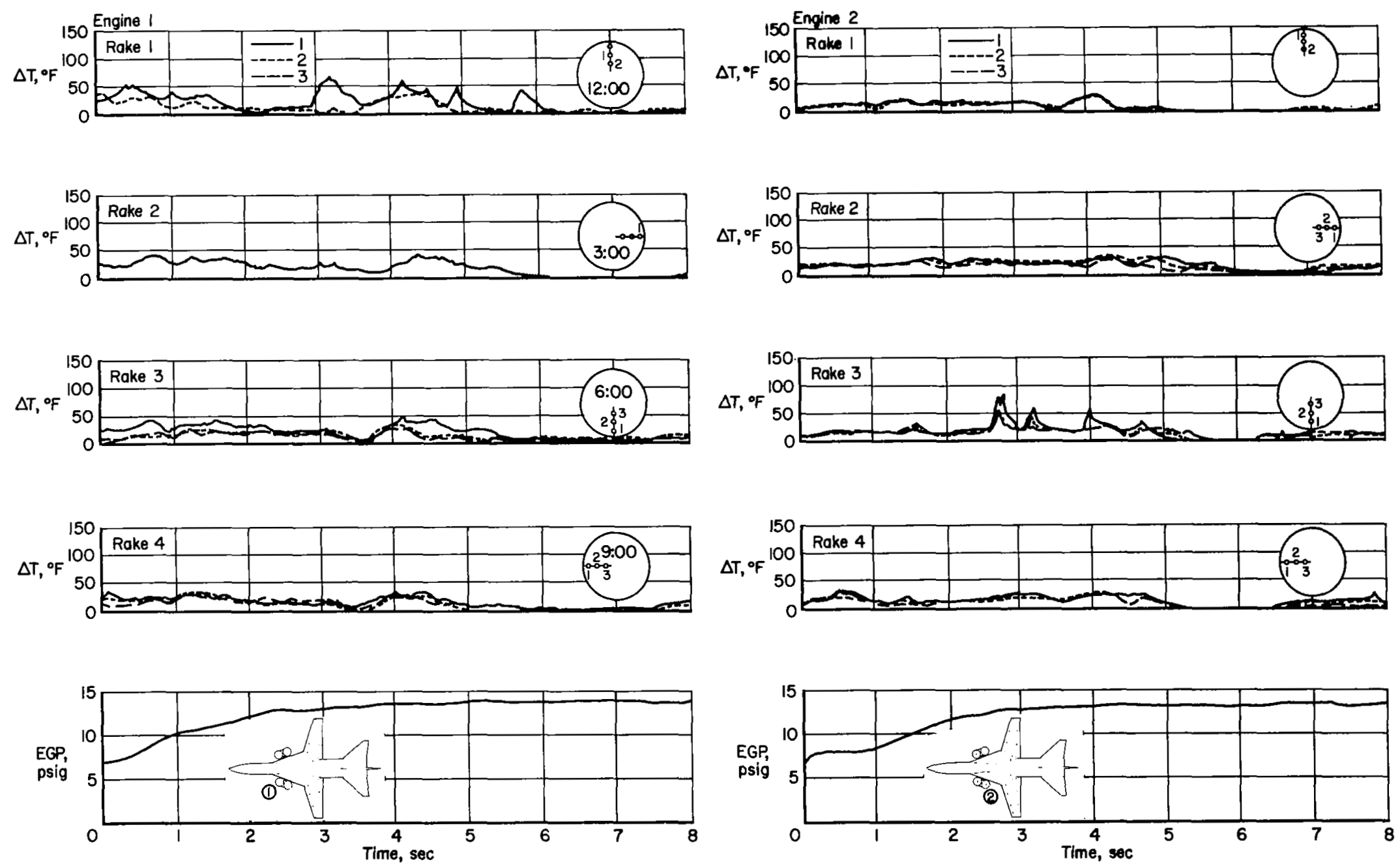

(a) Engine number 1 .

(b) Engine number 2.

Figure 7.- Measured temperature and pressure transients for the swiveling, retractable configuration; $\mathrm{H} / \mathrm{D}=5.0,20^{\circ}$ swivel plane, $\sigma_{\mathrm{L}}=90^{\circ}, \sigma_{\mathrm{C}}=70^{\circ}, \eta=15^{\circ}$. 

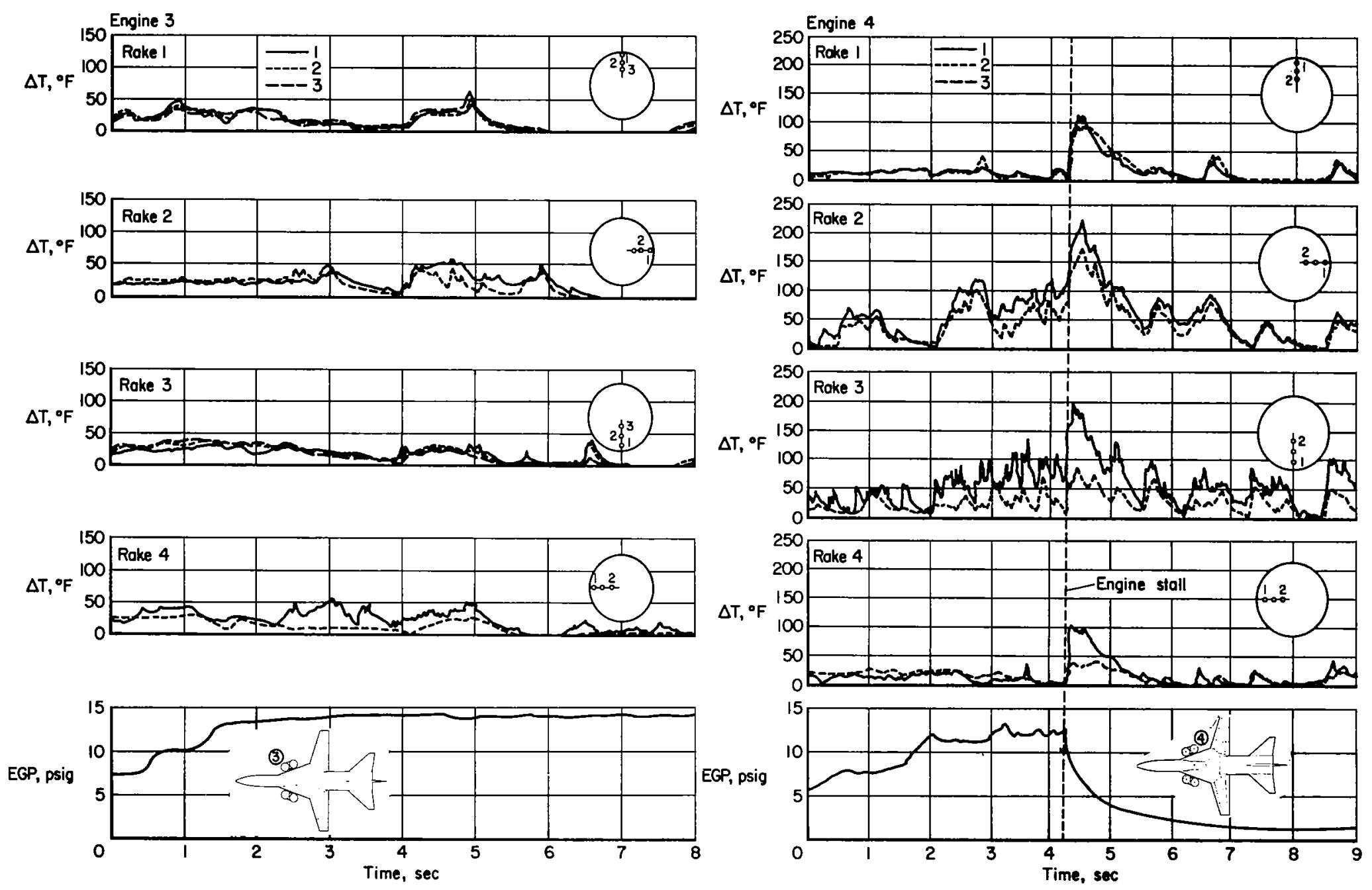

(c) Engine number 3 .

(d) Engine number 4.

Figure 7.- Concluded. 

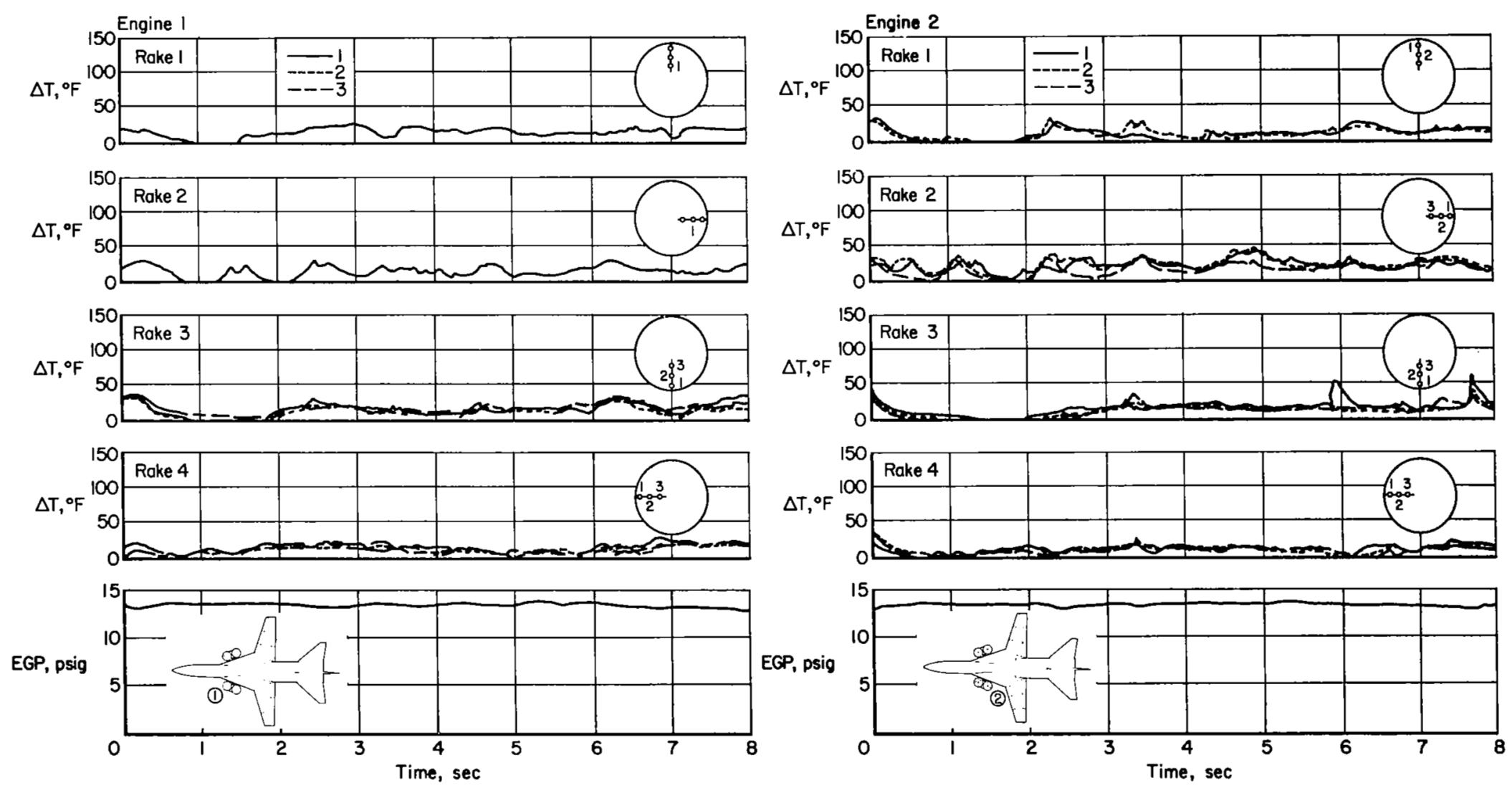

(a) Engine number 1 .

(b) Engine number 2.

Figure 8.- Measured temperature and pressure transients for the swiveling, retractable configuration; $\mathrm{H} / \mathrm{D}=5.0,20^{\circ}$ swivel plane, $\sigma_{\mathrm{L}}=80^{\circ}, \sigma_{\mathrm{C}}=70^{\circ}, \eta=15^{\circ}$. 

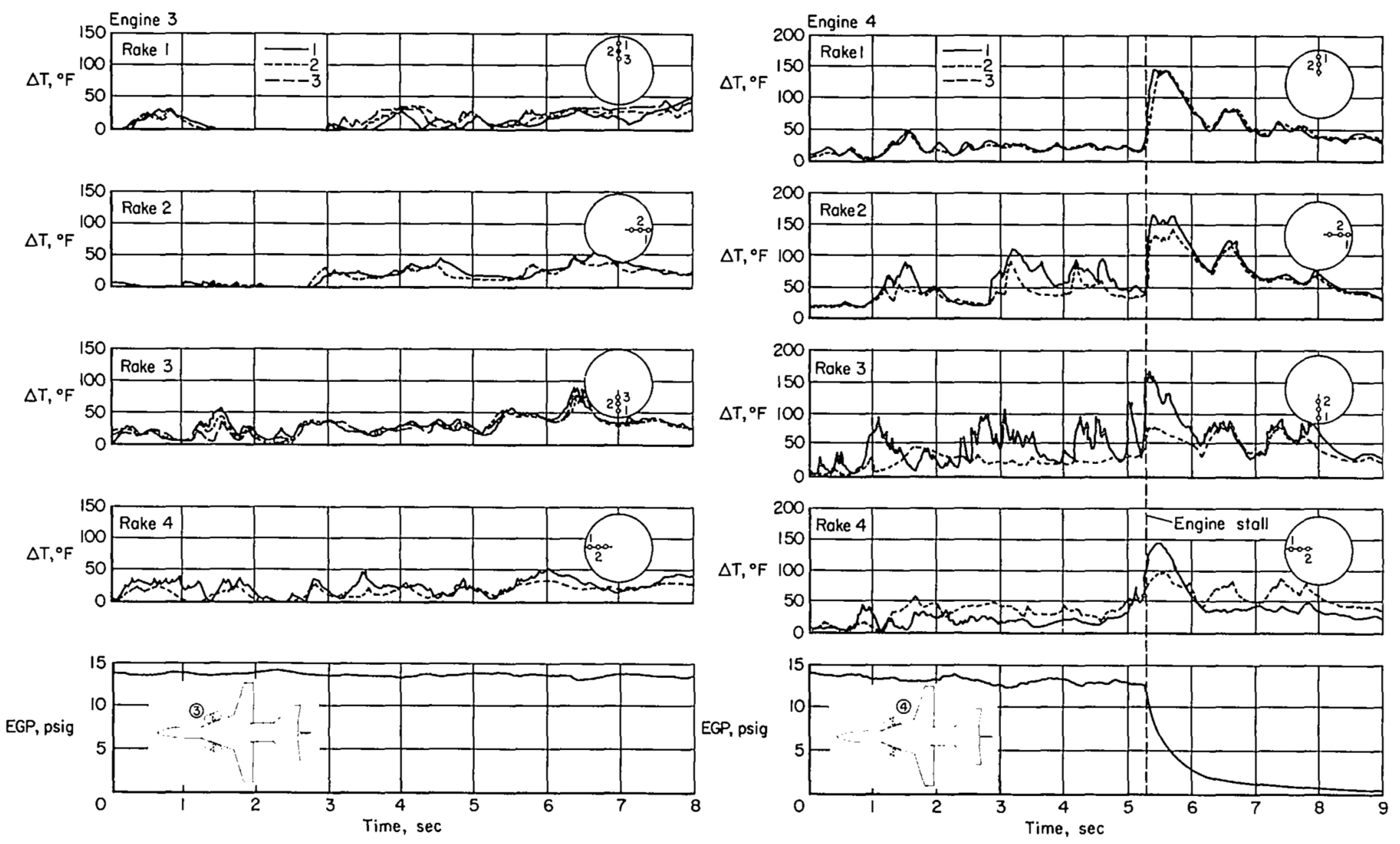

(c) Ingine number 3 .

(d) Engine number 4.

Figure 8.- Concluded. 

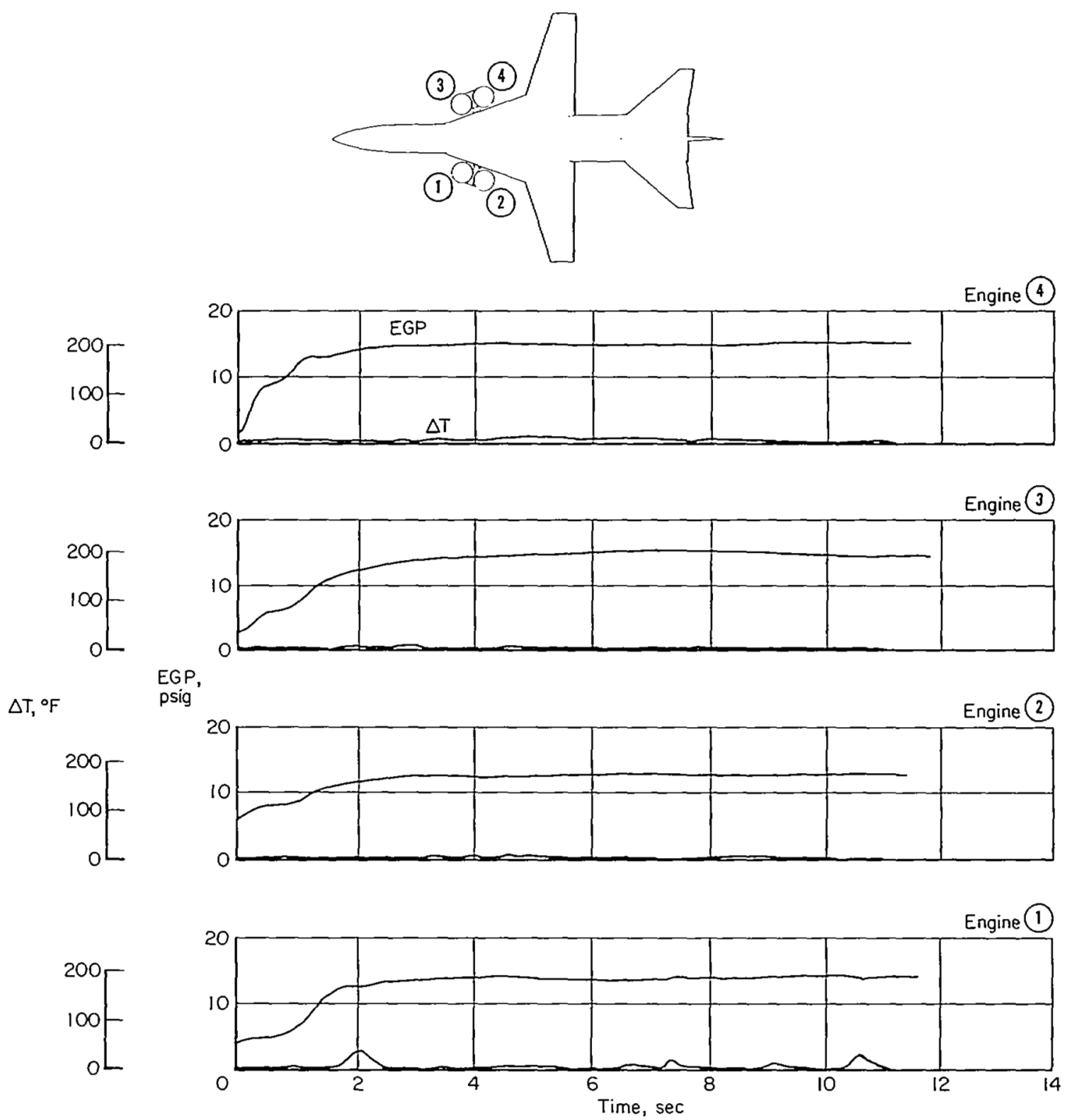

Figure 9.- Measured temperature and pressure transients for the swiveling, retractable configuration; $H / D=5.0,20^{\circ}$ swivel plane, $\sigma_{L}=70^{\circ}$, $\sigma_{\mathrm{C}}=65^{\circ}, \eta=15^{\circ}$. 

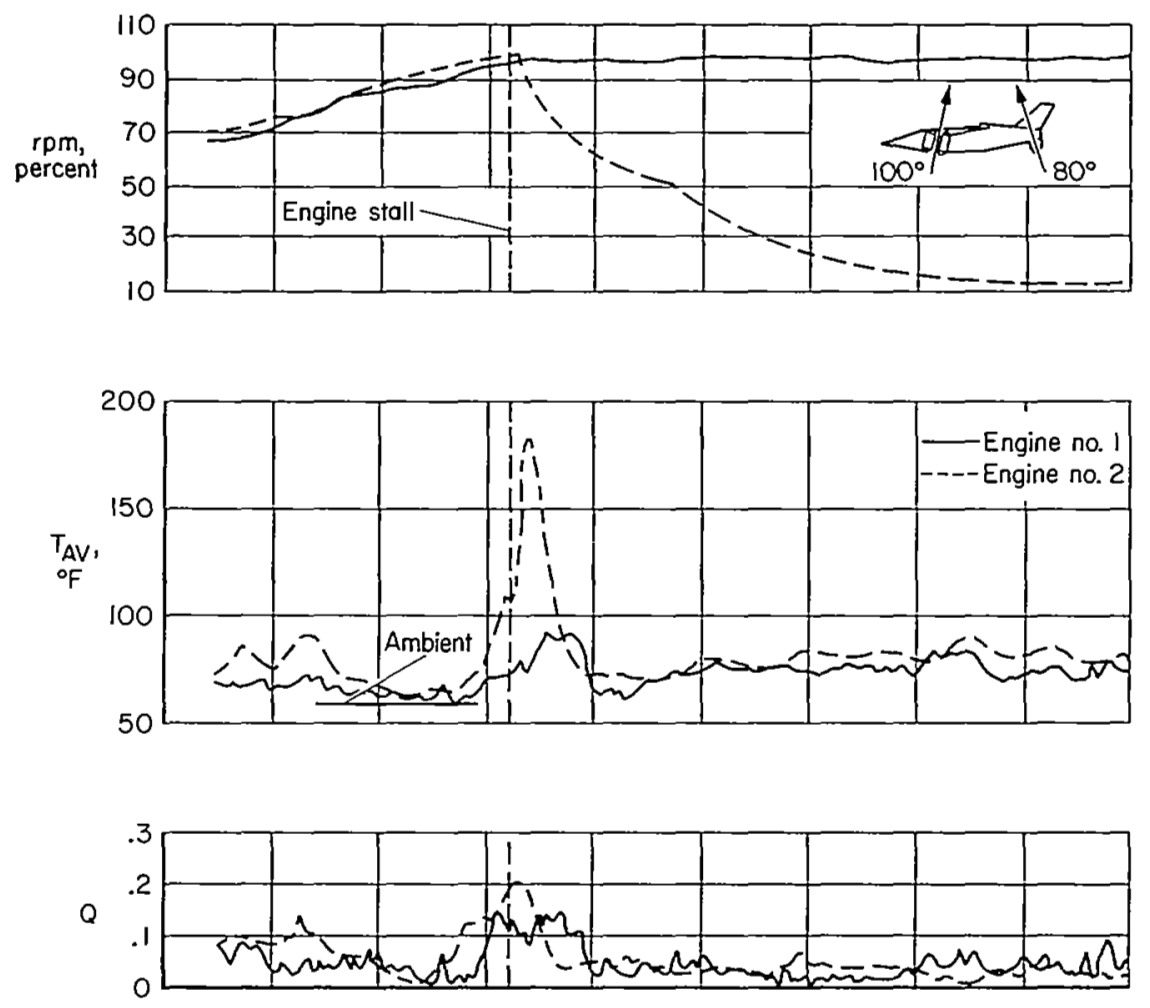

(a) $\sigma_{L}=100^{\circ}, \sigma_{C}=80^{\circ}, \eta=7^{\circ}$
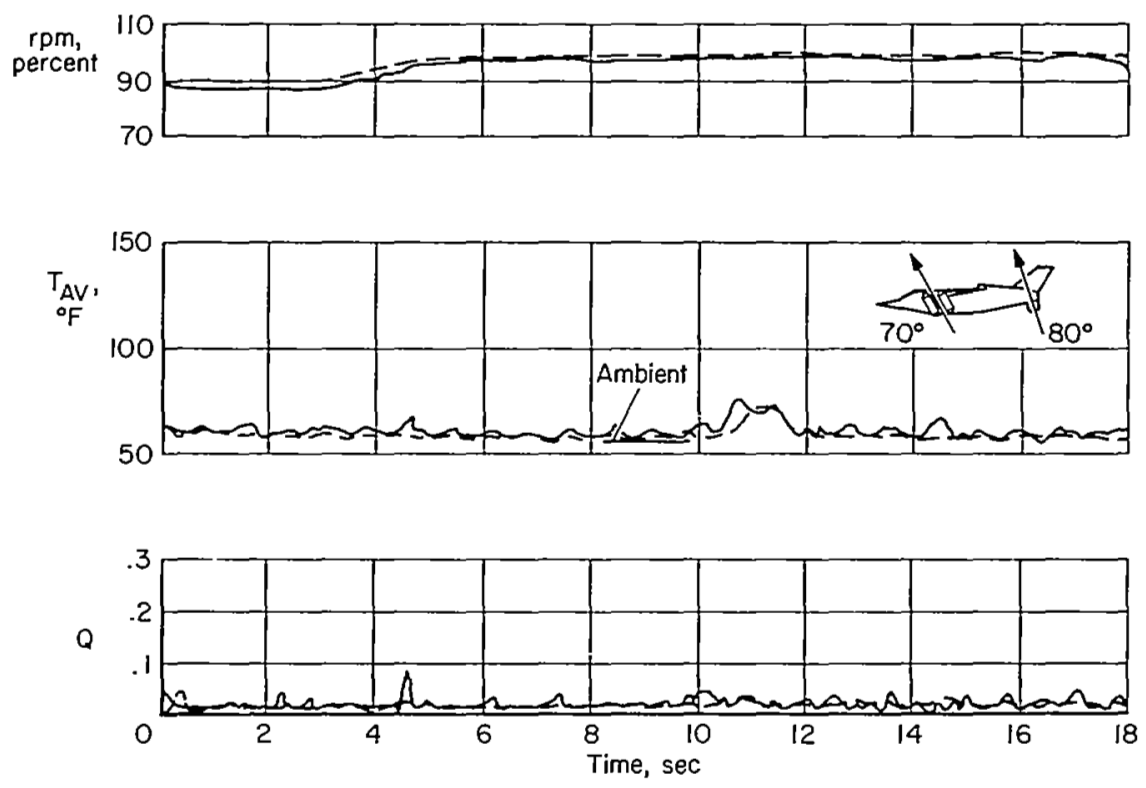

(b) $\sigma_{L}=70^{\circ}, \sigma_{C}=80^{\circ} ; \eta_{1}=0^{\circ}$

Figure 10.- Average inlet temperature and aistortion index for the swiveling, retractable configuration; $H / D=5.0,5^{\circ}$ swivel plane, duct extension installed. 


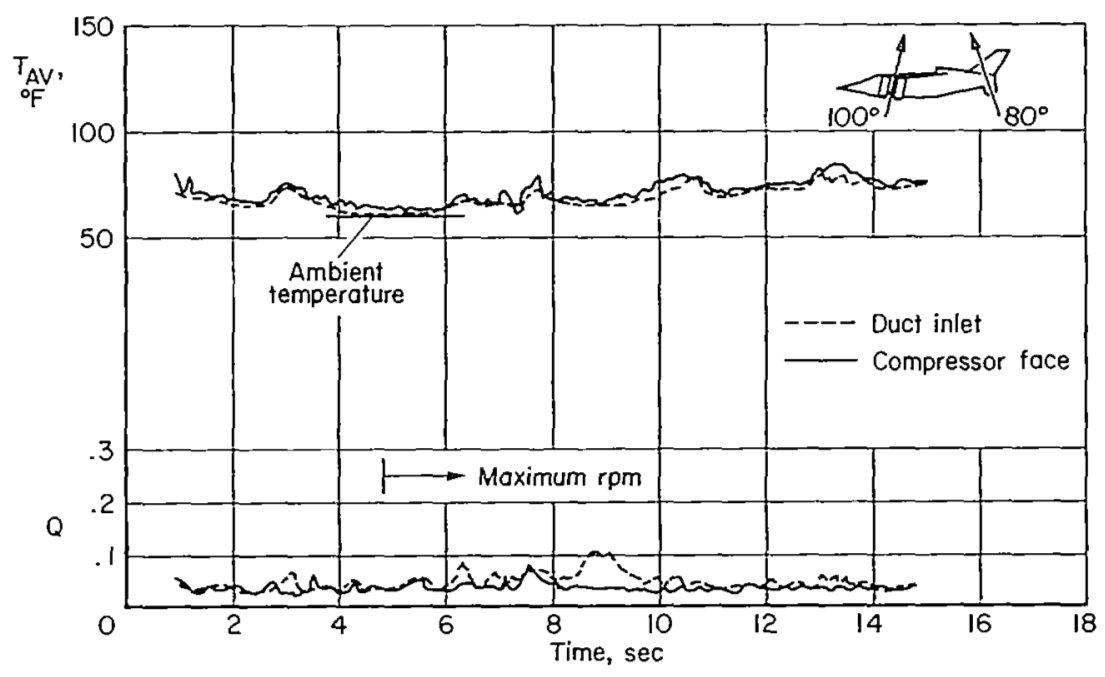

Figure 11.- The effect of an inlet duct extension as a mixing chamber on the average inlet temperature and temperature distortion on the left-hand liftcruise engine; swiveling, retractable configuration, $\mathrm{H} / \mathrm{D}=5.0, \sigma_{\mathrm{I}}=100^{\circ}$, $\sigma_{\mathrm{C}}=80^{\circ}, \eta=7^{\circ}, 5^{\circ}$ swivel plane. 

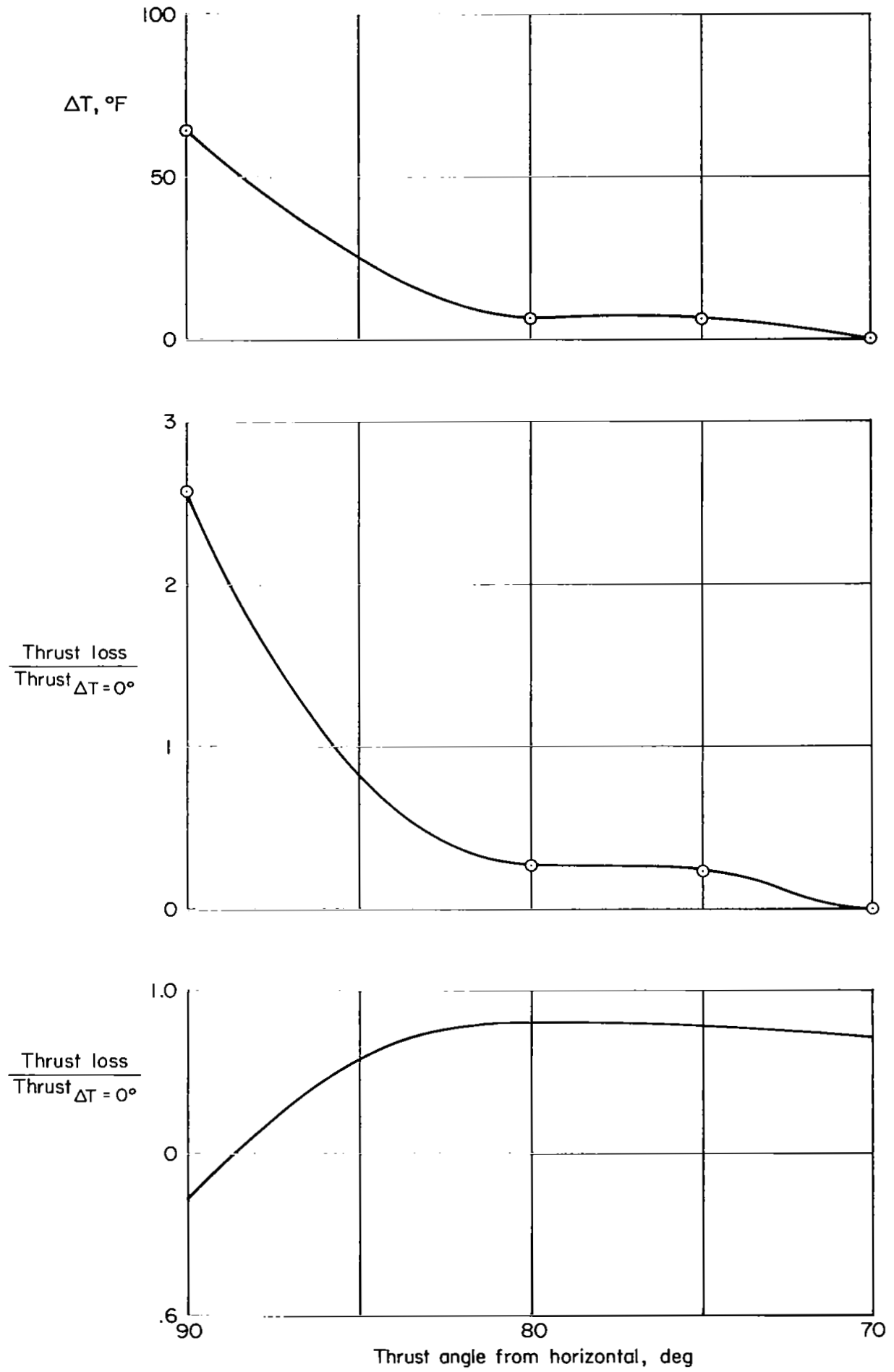

Figure 12.- The effect of exhaust vectoring on temperature rise and thrust loss; swiveling, retractable configuration; $\mathrm{H} / \mathrm{D}=5.0$. 

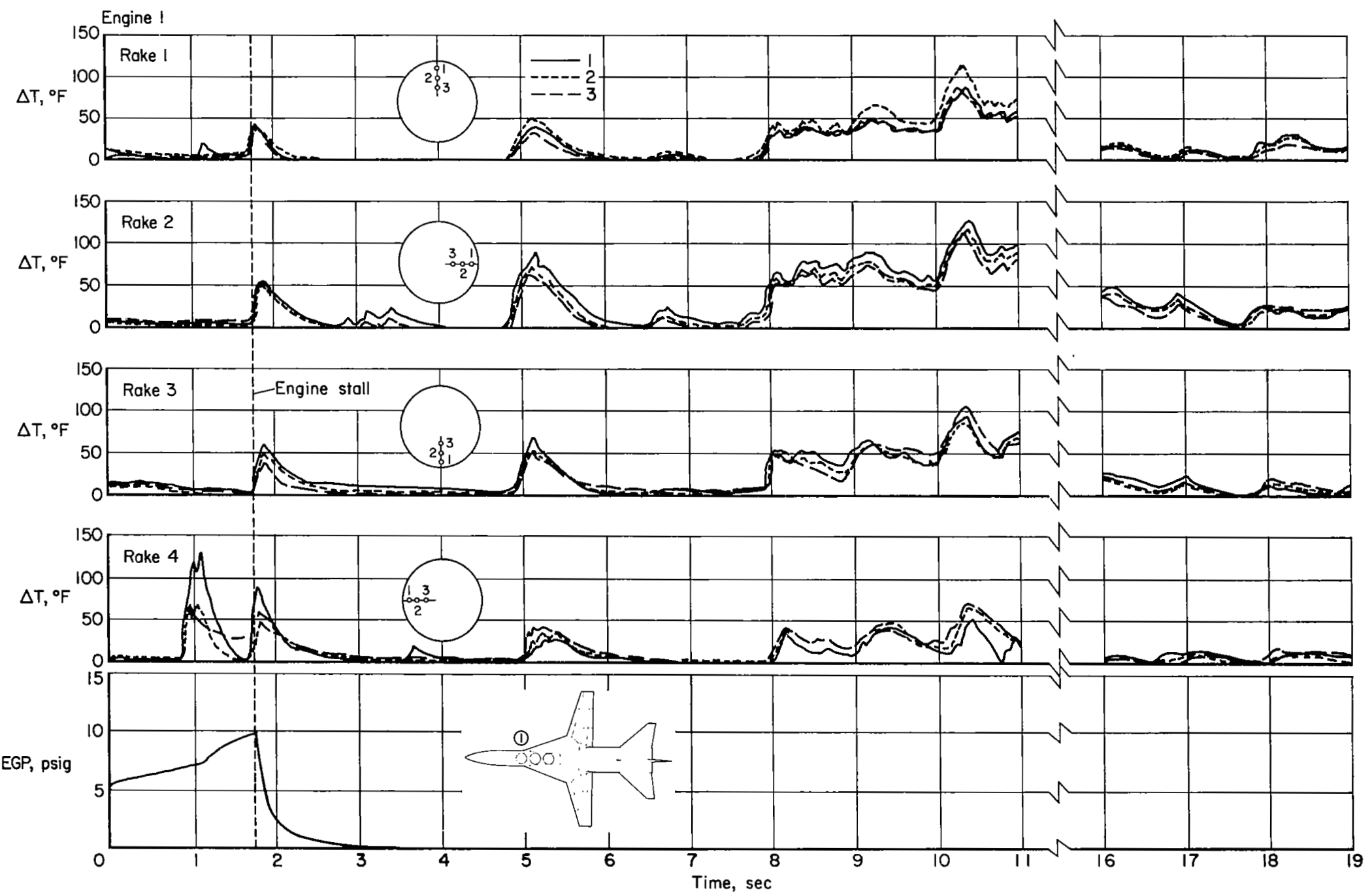

(a) Tngine number 1 .

Figure 13.- Measured temperature and pressure transients for the internally fixed configuration; $\mathrm{H} / \mathrm{D}=5.0$, bifurcated exit nozzles, $\sigma_{\mathrm{L}}=90^{\circ}, \sigma_{\mathrm{C}}=82^{\circ}$. 

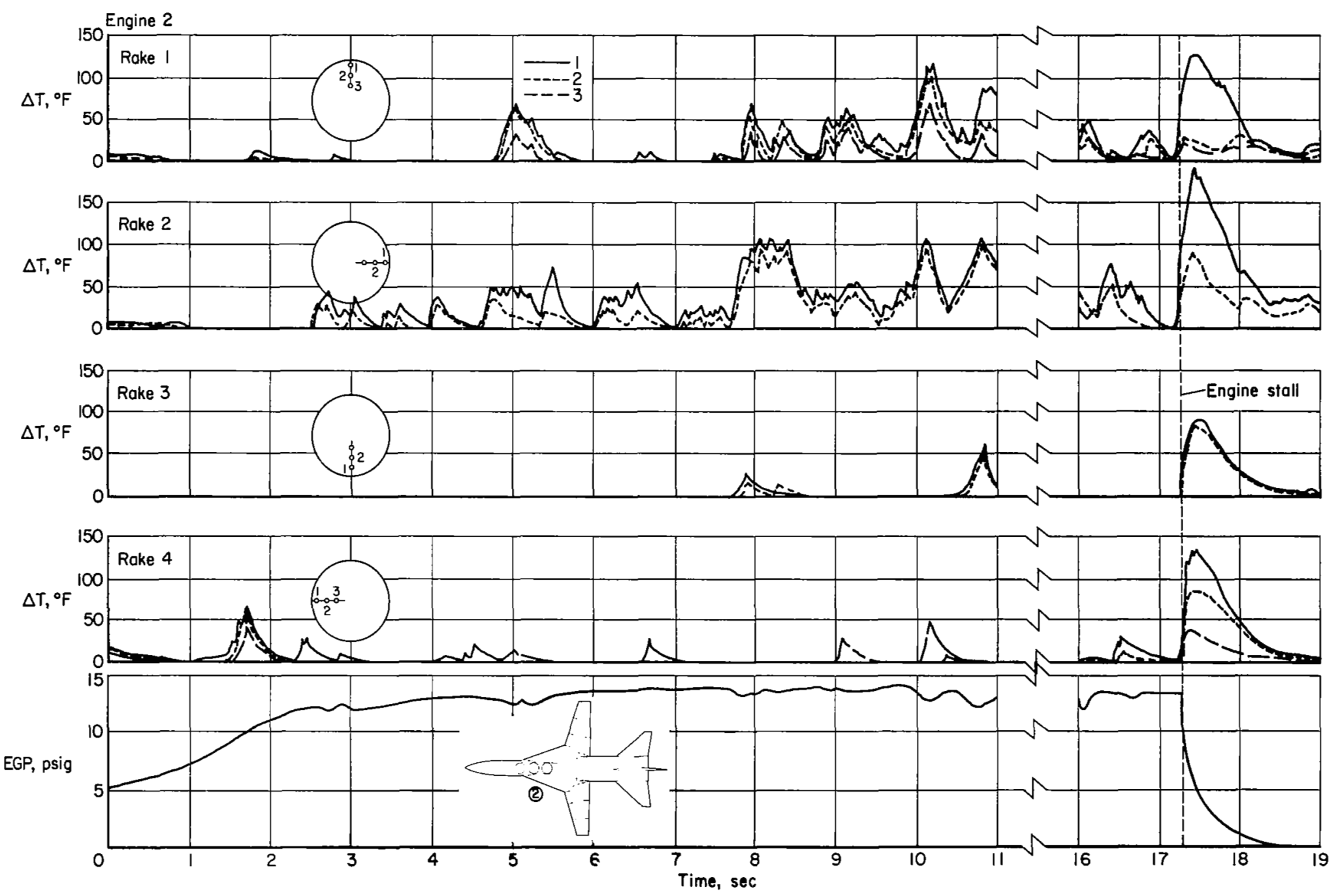

(b) Engine number 2.

Figure 13.- Continued. 

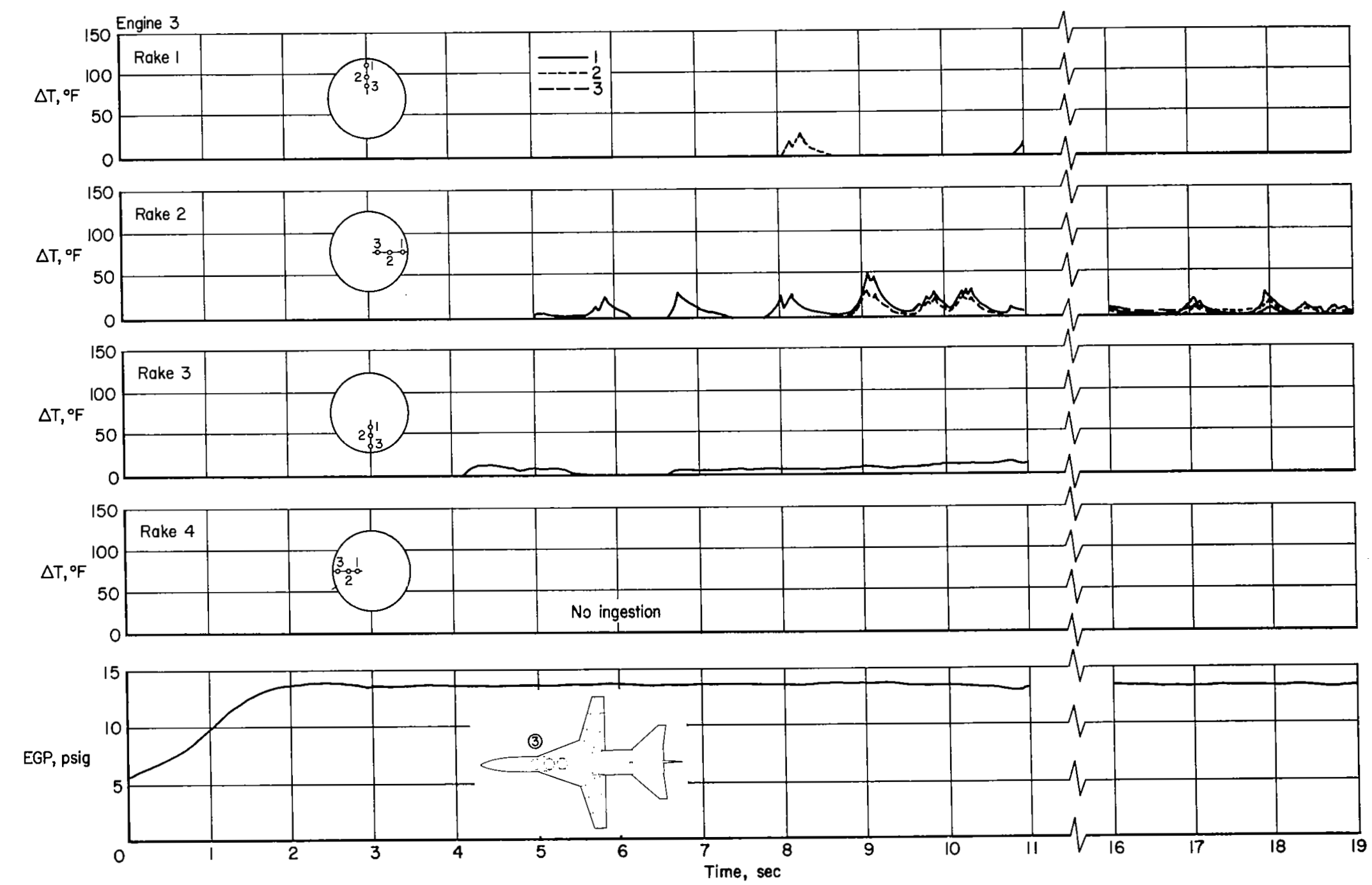

(c) Engine number 3 .

Figure 13.- Concluded. 

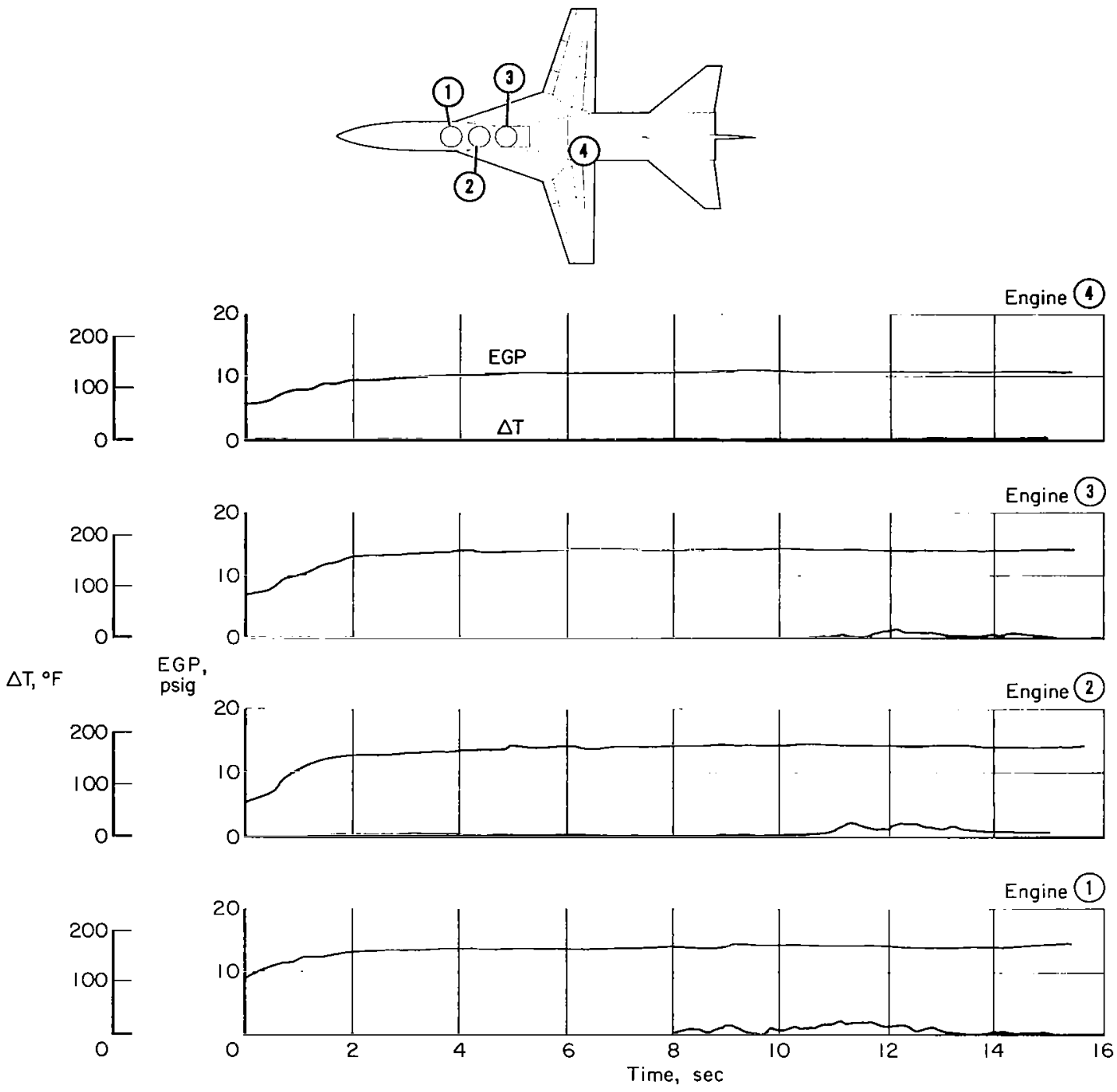

Figure 14.- Measured temperature and pressure transients for the internally fixed configuration; $\mathrm{H} / \mathrm{D}=5.0$, bifurcated exit nozzles, $\sigma_{\mathrm{L}}=75^{\circ}$, $\sigma_{\mathrm{C}}=75^{\circ}$. 

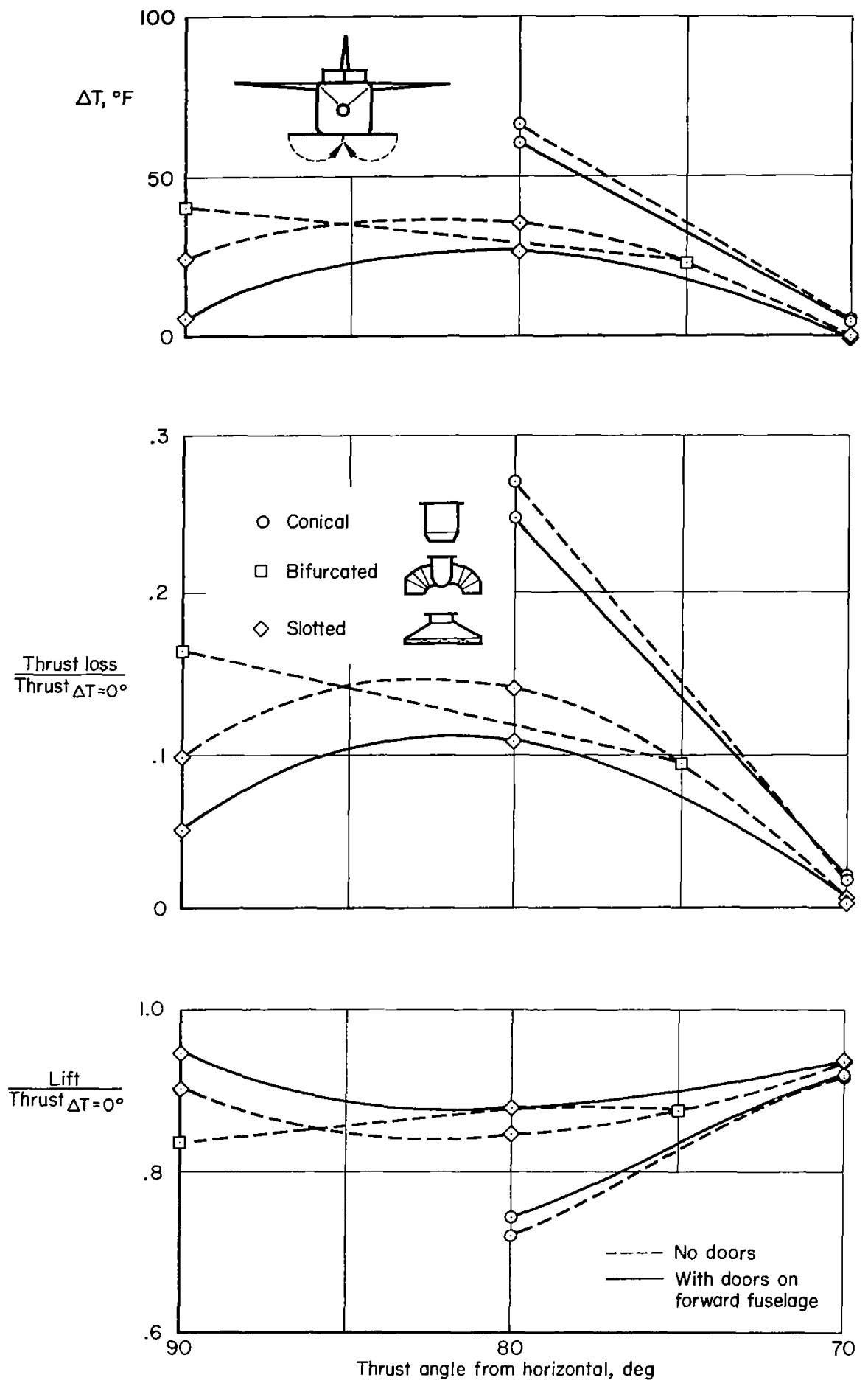

Figure 15.- The effect of exhaust vectoring on temperature rise and thrust loss; internally fixed configuration, $H / D=5.0$. 

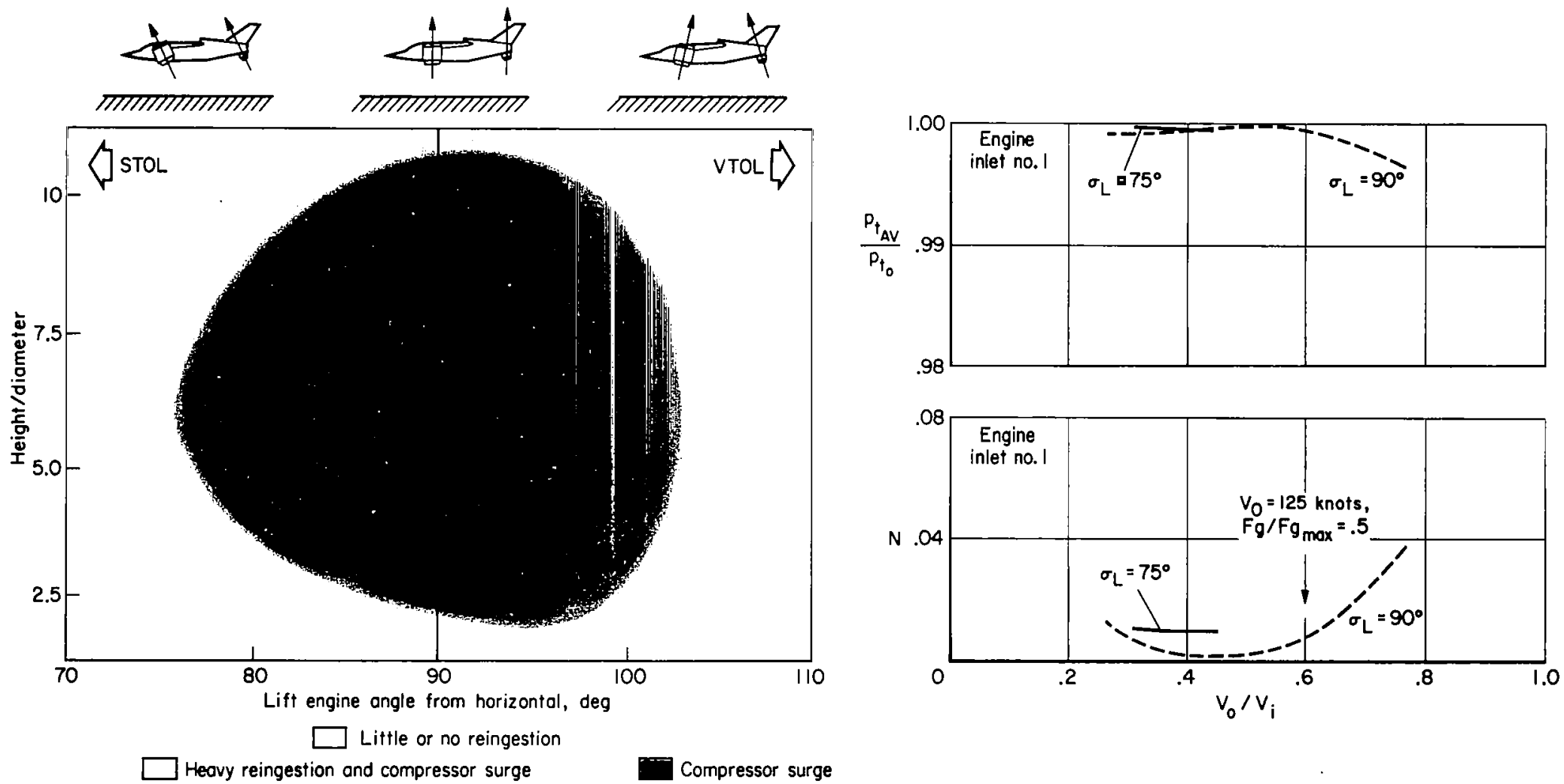

Figure 16.- General reingestion boundaries for the lift-engine fighter model; $\eta=15^{\circ}$.
Figure 17.- The effect of velocity ratio on inlet flow distortion and pressure recovery; swiveling, retractable configuration, $20^{\circ}$ swivel plane. 


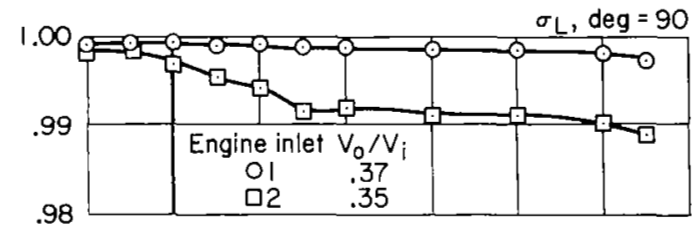

$\frac{P_{t_{A V}}}{P_{t_{0}}}$
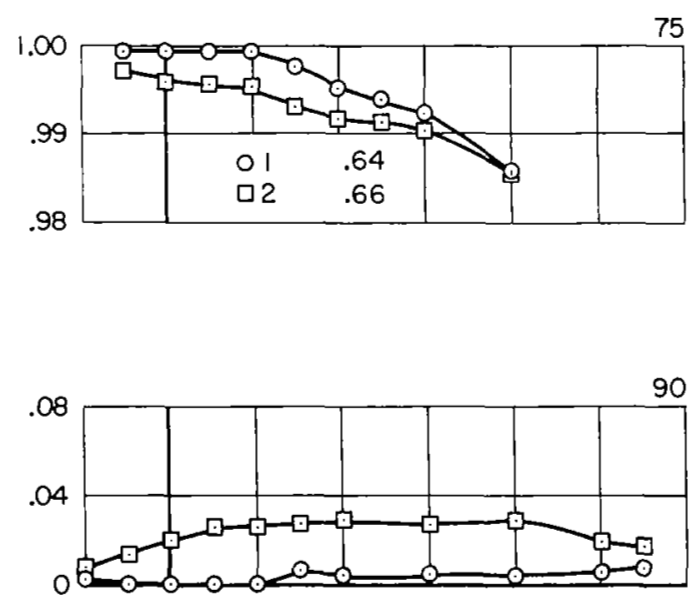

N

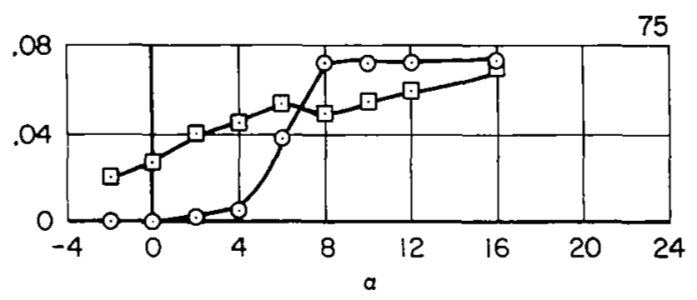

Figure 18.- The variation in flow distortion and pressure recovery with angle of attack; swiveling, retractable configuration, $20^{\circ}$ swivel plane.

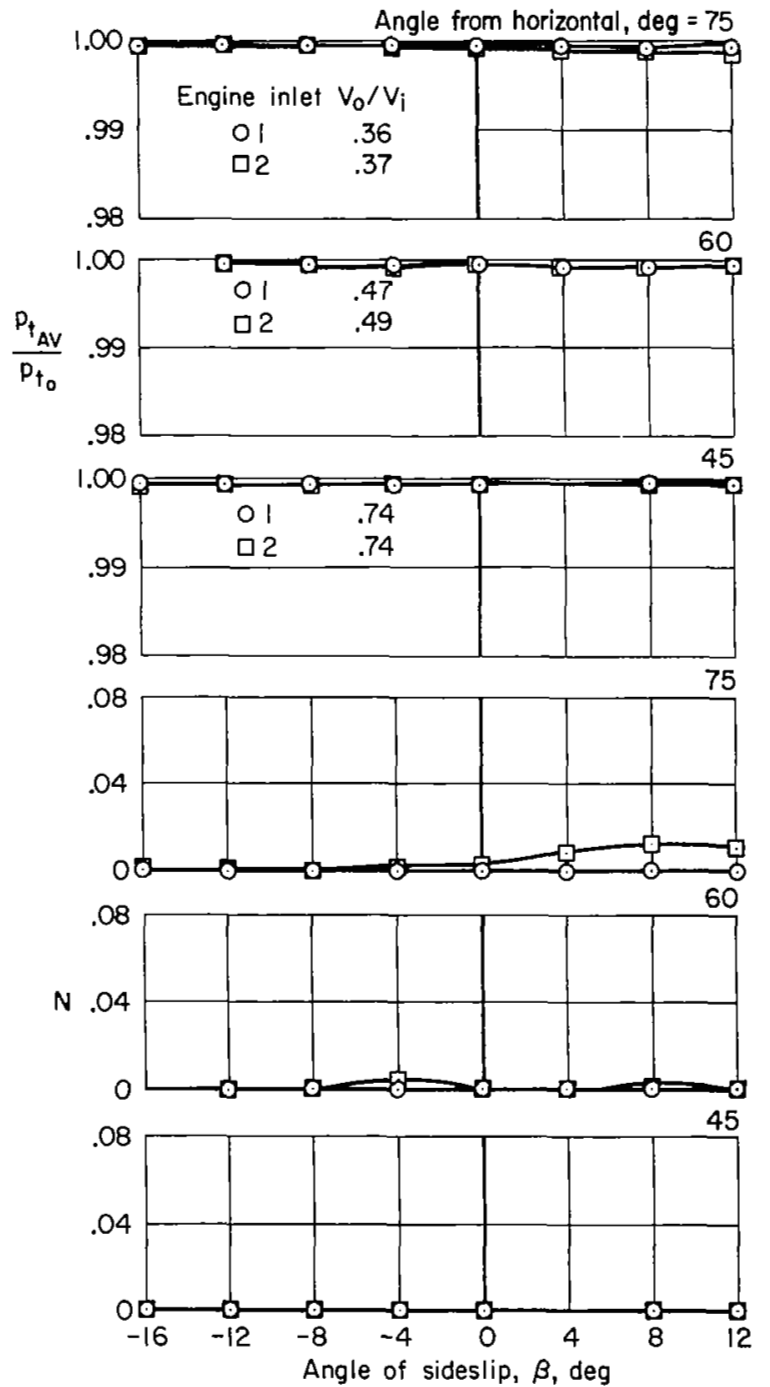

Figure 19.- The effect of sideslip angle on inlet flow distortion and pressure recovery; swiveling, retractable configuration. 

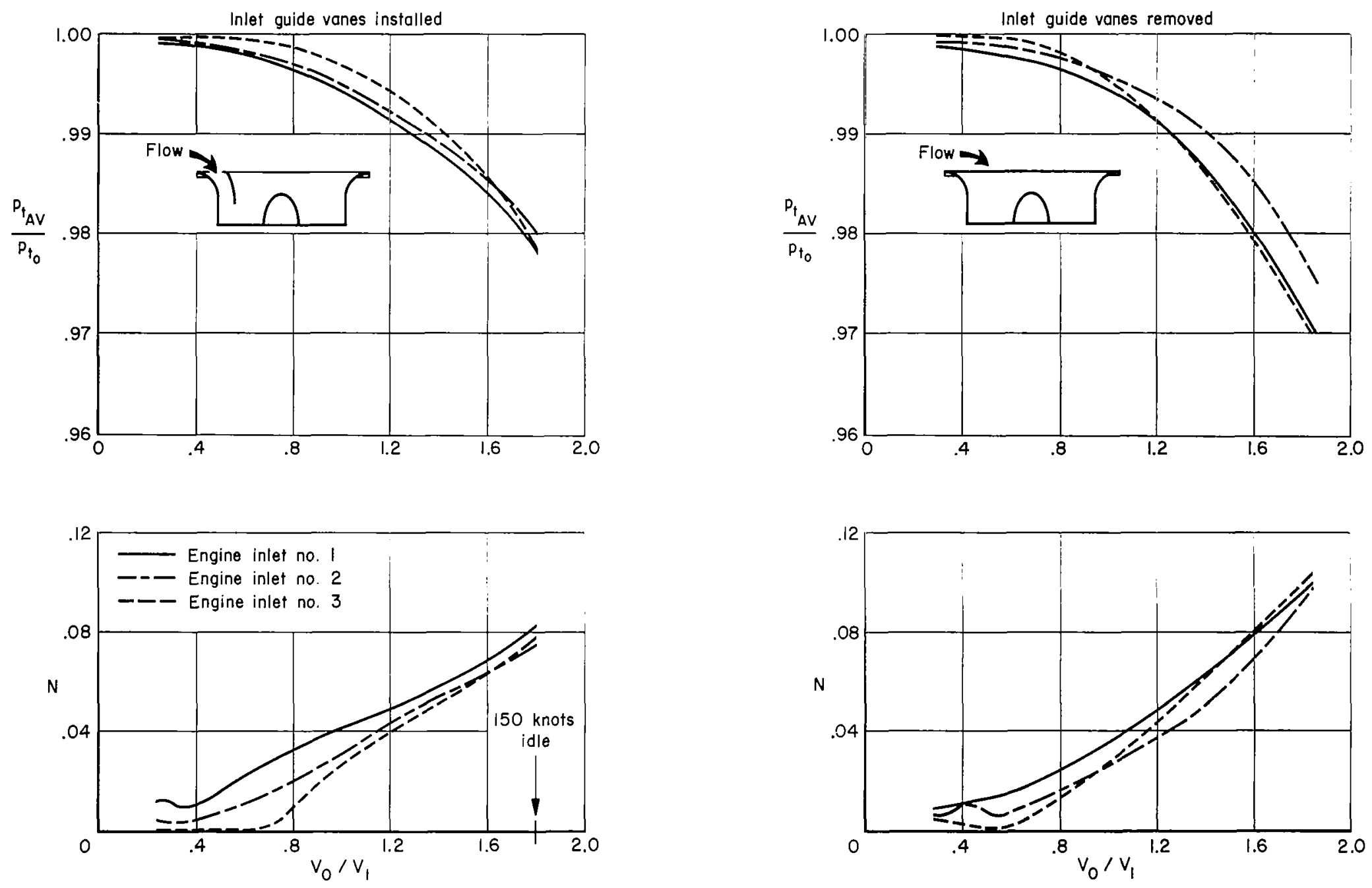

(a) Inlet guide vanes installed

(b) Inlet guide vanes removed

Figure 20.- The effect of velocity ratio on flow distortion and pressure recovery; internally fixed configuration, $\alpha=0^{\circ}, \beta=0^{\circ}$. 

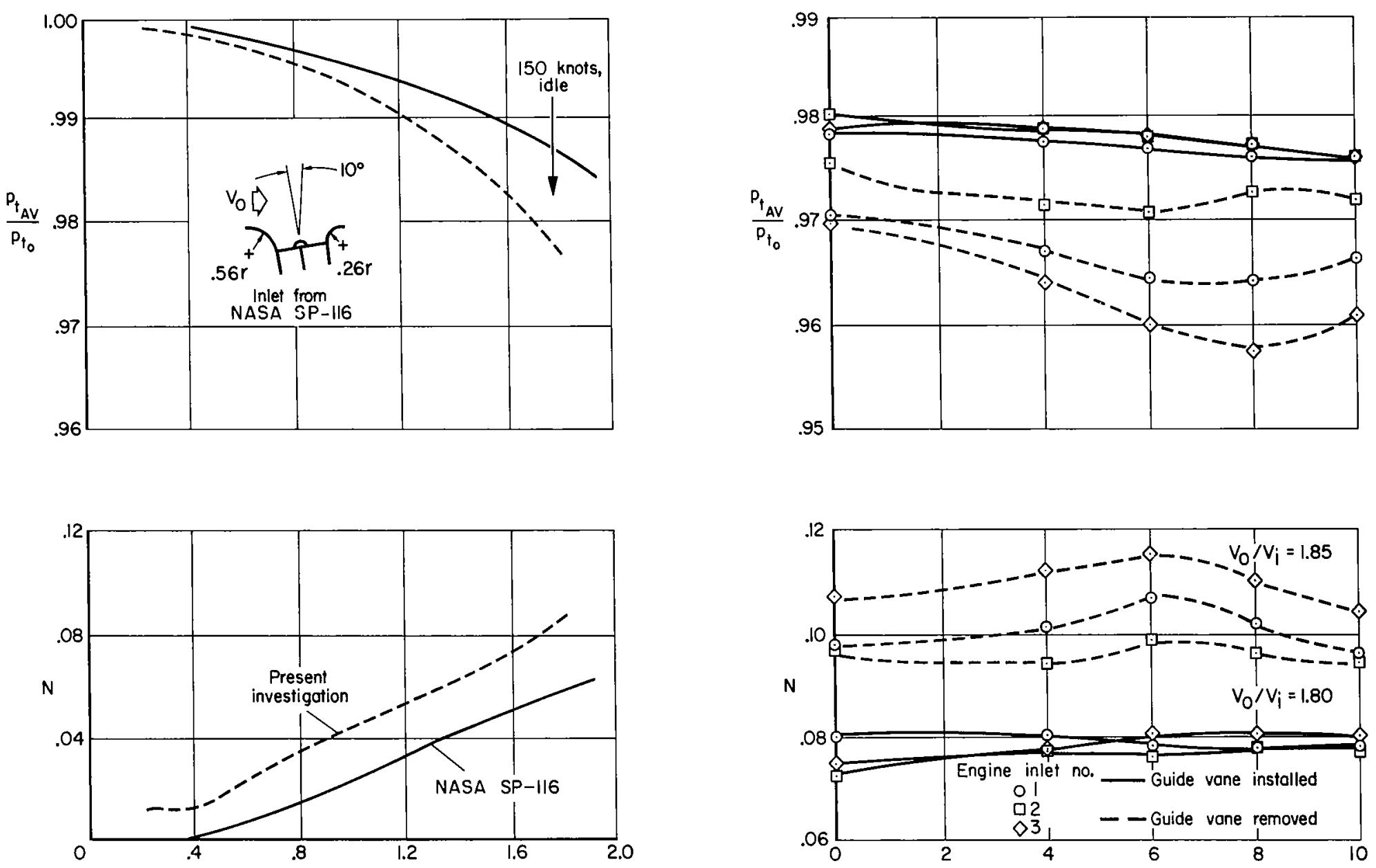

Figure 21. - The effect of engine tilt and inlet leading-edge radius on distortion and pressure recovery; number 1 engine.

Figure 22.- The variation in flow distortion and pressure recovery with angle of attack; internally fixed configuration, $V=150 \mathrm{kts}$, idle thrust, $\beta=10^{\circ}$. 

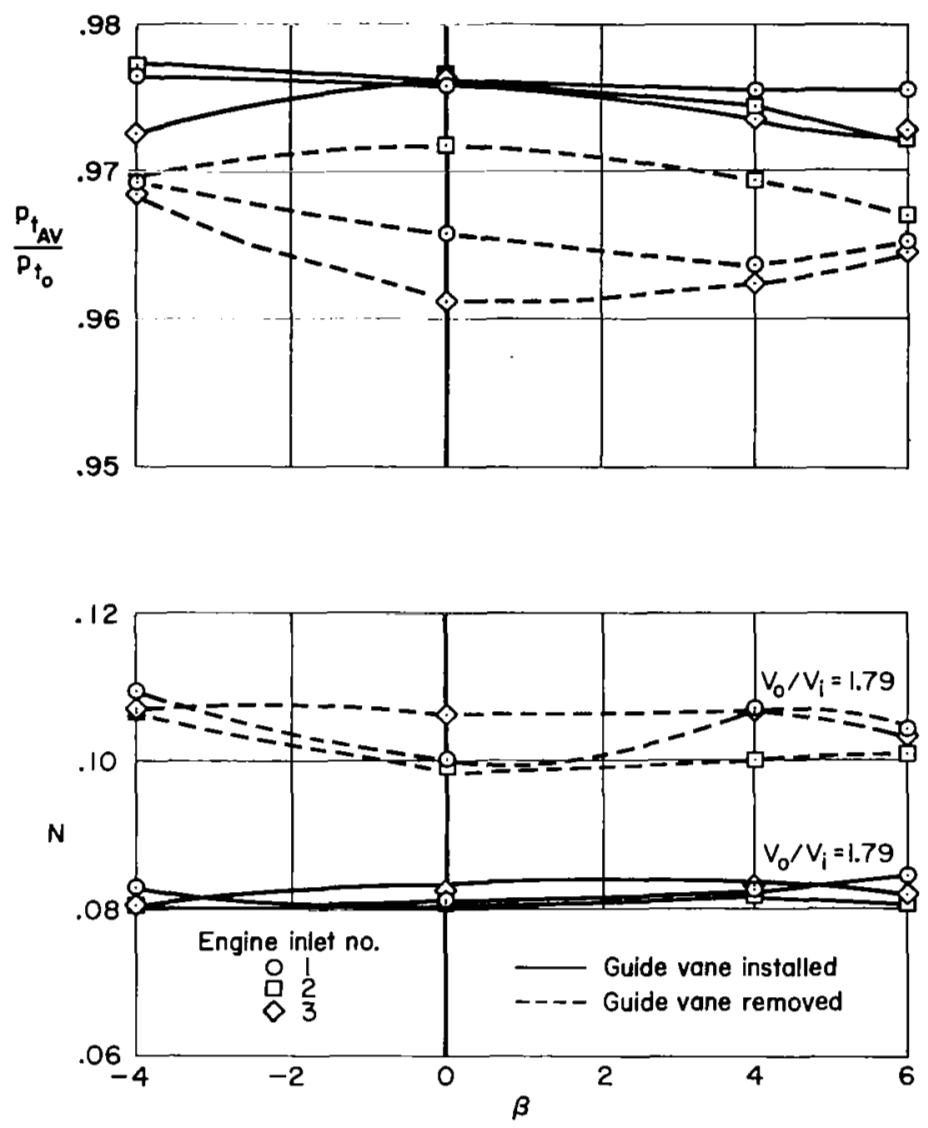

Figure 23.- The effect of sideslip angle on inlet flow distortion and pressure recovery; internally fixed configuration, $\mathrm{V}=150 \mathrm{kts}$, idle thrust, $\alpha=10^{\circ}$. 